\title{
The Supreme Court, Boys Markets Labor Injunctions, and Sympathy Work Stoppages
}

\author{
Arthur B. Smith, Jr.†
}

In Buffalo Forge Co. v. United Steelworkers, the Supreme Court ruled that federal courts may enjoin sympathy work stoppages after, but not before, an arbitrator determines that the strike or picket line respect violates a no-strike obligation in the governing collective bargaining agreement. Professor Smith finds the concerns that prompted the Court to restrict the availability of Boys Markets labor injunctions in this manner largely unfounded, given the possibility of enjoining the strike and ordering the controversy over the scope of the no-strike clause submitted to expedited arbitration. This alternative remedy would enhance respect for the collective bargaining agreement, satisfy the conditions for equitable intervention, and avoid the need for judicial construction of obscure National Labor Relations Board law concerning the protected status of sympathy strikes.

When Congress enacted section 301 of the Labor Management Relations Act, ${ }^{1}$ authorizing civil actions in federal courts for breach of collective bargaining agreements, it did not expressly amend the anti-injunction provisions of section 4 of the Norris-LaGuardia Act. ${ }^{2}$

$\dagger$ Assistant Professor of Industrial and Labor Relations, Cornell University.

- Section 301(a) of the Labor Management Relations Act (Taft-Hartley Act) provides:

Suits for violation of contracts between an employer and a labor organization representing employees in an industry affecting commerce as defined in this chapter, or between any such labor organization, may be brought in any district court of the United States having jurisdiction of the parties, without respect to the amount in controversy or without regard to the citizenship of the parties.

29 U.S.C. $\S 185$ (a) (1970). The legislative history of section 301 is summarized in H.R. REP. No. 510, 80th Cong., 1st Sess. (1947); 1 NLRB, Legislative History of the Labor MaNageMENT RELATIONS ACT, 1947, at 545-46, 570 (1948), and abstracted as an appendix to Justice Frankfurter's dissenting opinion in Textile Workers Union v. Lincoln Mills, 353 U.S. 448, 485546 (1957). For an analysis of the Court's use of this history, see Aaron, The Labor Injunction Reappraised, 10 U.C.L.A. L. REv. 292, 342-43 (1963).

2 Section 4 of the Norris-LaGuardia Act provides in pertinent part as follows:

No court of the United States shall have jurisdiction to issue any restraining order or temporary or permanent injunction in any case involving or growing out of any labor dispute to prohibit any person or persons participating or interested in such dispute (as these terms are herein defined) from doing, whether singly or in concert, any of the following acts:

(a) Ceasing or refusing to perform any work or to remain in any relation of employment;

(e) Giving publicity to the existence of, or the facts involved in, any labor dispute, whether by advertising, speaking, patrolling, or by any other method not involving fraud or violence;

(f) Assembling peaceably to act or to organize to act in promotion of their interests in a labor dispute; 
The extent to which injunctive relief is available to employers under section 301 for union breaches of collective bargaining contracts remains unresolved. In Buffalo Forge Co. v. United Steelworkers, ${ }^{3}$ the Supreme Court confronted this problem for the third time since 1970. Justice White, writing for a 5 to 4 majority, concluded that the compromise between competing policies fashioned in Boys Markets, Inc. v. Retail Clerks Union, Local 770, ${ }^{4}$ where the Court authorized equitable intervention in a limited category of breach-ofcontract strikes, should not be extended to permit preliminary injunctive relief against a sympathy work stoppage pending arbitration of the scope of the union's no-strike obligation. The decision thus marks a departure from the expansion of the Boys Markets remedy exhibited two terms earlier in Gateway Coal Co. v. United Mine Workers. ${ }^{5}$

On the surface, the slimness of the Court majority in Buffalo Forge, and the alignment of the authors of Boys Markets and Gateway Coal, Justice Brennan and Justice Powell respectively, with the dissenting opinion of Justice Stevens, might suggest a significant controversy and a return to the era of Sinclair Refining Co. $v$. Atkinson. ${ }^{6}$ That 5 to 4 decision, in which Justice Brennan wrote for the dissent, had precluded federal courts from enjoining breachof-contract strikes, and was overruled by Boys Markets. Neither opinion in Buffalo Forge questions the continuing vitality of Boys Markets, however, and the difference between the majority and minority positions is in fact quite small.

This article examines the soundness of the Buffalo Forge majority's contention that prearbitration injunctions against sympathy work stoppages and picket line respect would impair the policy favoring arbitration of labor disputes. The analysis concludes that the Court overlooked significant labor policies that would be furthered by permitting injunctions enforcing union no-strike obliga-

(i) Advising, urging, or otherwise causing or inducing without fraud or violence the acts heretofore specified, regardless of any such undertaking or promise as is described [in section 103 rendering so-called "yellow dog" contracts nonenforceablel.

29 U.S.C. $\S 104$ (1970).

3428 U.S. 397 (1976).

- 398 U.S. 235 (1970). See generally Gould, On Labor Injunctions, Unions and the Judges: The Boys Market Case, 1970 SuP. CT. Rev. 215; Note, Labor Injunctions, Boys Markets, and the Presumption of Arbitrability, 85 HARv. L. Rev. 636 (1972); Note, The New Federal Law of Labor Injunctions, 79 YALE L.J. 1593 (1970).

5414 U.S. 368 (1974).

- 370 U.S. 195 (1962). 
tions, ${ }^{7}$ and exaggerated the difficulties posed by judicial construction of ambiguous no-strike clauses in preliminary injunction proceedings. These problems, and the fear of unwarranted intrusion into union-management relations by judicial interpretation of obscure National Labor Relations Board law concerning the protected status of sympathy strikes and picket line respect, could largely be eliminated by the use of injunctive orders that do no more than preserve the status quo pending expedited arbitration of the scope of a union's no-strike obligation.

\section{The Boys Markets Compromise}

In Boys Markets the Supreme Court accommodated section 301 and the seemingly absolute anti-injunction strictures of the Norris-

- LaGuardia Act by invoking the policy developed under section 301 favoring arbitration as a mechanism for settling labor disputes. ${ }^{8}$ The Court recognized a limited employer's right to injunctive relief, conditioned on the existence of a "strike ... over a grievance which both parties are contractually bound to arbitrate"g and the satisfaction of ordinary principles of equity. In so ruling, Boys Markets rectified two aberrations in section 301 law created by Sinclair Refining $C o$. v. Atkinson: ${ }^{10}$ the apparent deemphasis of arbitration as a preferred

' For pre-Sinclair commentary on specific performance of no-strike obligations, see Cox, Current Problems in the Law of Grievance Arbitration, 30 RockY MT. L. REv. 247 (1958); Gregory, The Law of the Collective Agreement, 57 MrCH. L. Rev. 635 (1959); Mendelsohn, Enforceability of Arbitration Agreements Under Taft-Hartley Section 301, 66 YALE L.J. 167 (1956); Rice, A Paradox of Our National Labor Law, 34 MaRq. L. REv. 233 (1951); Stewart, No-Strike Clauses in the Federal Courts, 59 Mich. L. Rev. 673 (1961); Comment, Labor Injunctions and Judge-Made Labor Law: The Contemporary Role of Norris-LaGuardia, 70 YALE L.J. 70 (1960). Post-Sinclair commentary has focused on the viability of the specific performance remedy in state courts. See Aaron, Labor Injunctions in the State Courts (pts. 1 \& 2), 50 VA. L. REv. 951, 1147 (1964); Keene, The Supreme Court, Section 301 and NoStrike Clauses: From Lincoln Mills to Avco and Beyond, 15 Vil.. L. Rev. 32 (1969); Note, Specific Enforcement of No-Strike Clauses: The Enigma of Sinclair v. Atkinson, 19 RUTGERS L. REv. 507 (1965).

8 See United Steelworkers of America v. American Mfg. Co., 363 U.S. 564 (1960); United Steelworkers of America v. Warrior \& Gulf Nav. Co., 363 U.S. 574 (1960); United Steelworkers of America v. Enterprise Wheel \& Car Corp. 363 U.S. 593 (1960).

- 398 U.S. at 254, quoting Sinclair Ref. Co. v. Atkinson, 370 U.S. 195, 228 (1962) (Brennan, J., dissenting).

10 Criticism of the Court's reasoning and result in Sinclair was extensive and was acknowledged, in part, by the Court in Boys Markets. 398 U.S. at 249 n.18; see, e.g., SEcTion of Labor Relations Law, ABA, Report of Special AtKinson-Sinclatr Committee 226-44 (1963); Aaron, The Labor Injunction Reappraised, 10 U.C.L.A. L. Rev. 292 (1963); Aaron, Strikes in Breach of Collective Agreements: Some Unanswered Questions, 63 Colum. L. Rev. 1027 (1963); Bartosic, Injunctions and Section 301: The Patchwork of Avco and Philadelphia Marine on the Fabric of National Labor Policy, 69 CoLuM. L. Rev. 980 (1969); Dunau, Three Problems in Labor Arbitration, 55 VA. L. Rev. 427, 463-68 (1969); Keene, The Supreme Court, 
method of resolving labor disputes, and the frustration of the policy favoring uniform remedies for breach of collective agreements, since injunctive relief theoretically remained available in state as opposed to federal courts. ${ }^{11}$

Both Sinclair and Boys Markets dealt with collective bargaining agreements containing grievance procedures that culminated in final and binding arbitration. ${ }^{12}$ These procedures could be invoked by either party, and applied to all disputes involving the interpretation of the bargaining agreements. Both agreements also contained express no-strike clauses prohibiting strikes over any matter that could have been resolved in the grievance-arbitration process. ${ }^{13}$ The employees in both cases struck over disputes with management that were subject to, and resolvable under, the grievance-arbitration provisions of the collective agreements. ${ }^{14}$

In Sinclair, Justice Black's majority opinion rejected the argument advanced by some commentators ${ }^{15}$ that a strike in breach of contract is not a "labor dispute" within the meaning of section 13(c) of the Norris-LaGuardia Act. ${ }^{16}$ According to Justice Black, because

Section 301 and No-Strike Clauses: From Lincoln Mills to Avco and Beyond, supra note 7; Wellington, The No-Strike Clause and the Labor Injunction: Time for a Re-examination, 30 U. PIrT. L. REv. 293 (1968); Wellington \& Albert, Statutory Interpretation and the Political Process: A. Comment on Sinclair v. Atkinson, 72 YaLE L.J. 1547 (1963). But see Vladeck, Boys Markets and National Labor Policy, 24 VAND. L. REv. 93 (1970) (arguing that Sinclair was essentially correct insofar as judicial intervention is concerned and that breaches of no-strike clauses should be treated as prima facie violations of the NLRA subject to Board jurisdiction).

"See text and note at note 98 infra.

12 The grievance-arbitration provisions of the collective bargaining agreement involved in Sinclair are reproduced in an appendix to the opinion of the Court in a companion case, Atkinson v. Sinclair Ref. Co., 370 U.S. 238, 250-53 (1962). The grievance-arbitration provisions relevant in the Boys Markets case are reproduced in the district court's opinion. 70 L.R.R.M. 3071, 3072-74 (C.D. Cal. 1969).

13 See Sinclair Ref. Co. v. Atkinson, 290 F.2d 312, 315 (7th Cir. 1961). The no-strike provisions in Boys Markets were equally broad in scope but were inapplicable if the employer refused to arbitrate a dispute subject to the grievance-arbitration procedure or failed to abide by an arbitration award. See 70 L.R.R.M. at 3073.

14 The grievances in Sinclair involved allegedly improper deductions by the employer from three employees' pay, the refusal of the employer to assign riggers to work alongside other crafts on certain jobs, the refusal by the employer to employ certain apprentices at craft level jobs and pay, and an allegedly improper subcontracting of bargaining unit work. See 370 U.S. at 199 n.10. In Boys Markets, the dispute concerned the use of nonunion employees to rearrange merchandise in the frozen food cases in one of the employer's supermarkets, work which the union claimed belonged to its members. 398 U.S. at 239.

is See, e.g., Gregory, supra note 7; Rice, supra note 7; Stewart, supra note 7.

16370 U.S. at 199. The Norris-LaGuardia Act defines the term "labor dispute" in pertinent part as "any controversy concerning terms or conditions of employment, or concerning the association or representation of persons in negotiating, fixing, maintaining, changing, or seeking to arrange terms or conditions of employment, regardless of whether or not the disputants stand in the proximate relation of employer and employee." 29 U.S.C. $\$ 113$ (c) (1970). For an analysis concluding that a strike in breach of contract is a "labor dispute" 
the breach of contract strike was a "labor dispute," section 4 of the Norris-LaGuardia Act applied unless it had been repealed by section 301 . He concluded that the anti-injunction provisions had not been repealed by section 301, and he refused to accept the dissent's solution accommodating section 4 of the Norris-LaGuardia Act with the subsequently enacted section $301 .{ }^{17}$ Consequently, federal courts were deprived of the power to enjoin strikes in breach of contract.

As he had argued in the Sinclair dissent, Justice Brennan, writing for the majority in Boys Markets, adopted the proposition that the anti-injunction provisions of the Norris-LaGuardia Act had to be accommodated with section $301 .^{18}$ In determining the proper scope of the accommodation, he focused primarily on the importance of arbitration as an instrument of substantive federal labor law. Thus, a court's power to issue an injunction was conditioned on the existence of a grievance-arbitration procedure fully capable of resolving the dispute that had caused the strike. Justice Brennan reasoned that a remedial device that did no more than enforce a union's freely undertaken obligation to arbitrate did not contravene the policies of the Norris-LaGuardia Act.

Justice Brennan also emphasized "the devastating implications for the enforceability of arbitration agreements and their accompanying no-strike obligations if equitable remedies were not available." 19 Noting that an employer's promise to submit disputes to the process of arbitration is generally given as a quid pro quo for the union's agreement not to strike, he suggested that employers would have little incentive to agree to arbitration if the most expeditious

within the meaning of the language quoted above, see United States v. UMW, 330 U.S. 258, 312-13 (1947) (Frankfurter, J., concurring).

Cases permitting state court injunctions of breaches of contract despite little NorrisLaGuardia acts with provisions identical to section 13(c) of the federal statute, and little Norris-LaGuardia acts with specific language exempting strikes in breach of collective bargaining agreements from their anti-injunction provisions, are collected in Aaron, Labor Injunctions in the State Courts (pt. 1), 50 VA. L. REv. 951, 981 (1964); Keene, supra note 7, at $49 \mathrm{nn} .79$ \& 80; and Note, Specific Enforcement of No-Strike Clauses: The Enigma of Sinclair v. Atkinson, 19 Rutgers L. REv. 507, 526 (1965).

${ }_{17}$ See Sinclair v. Atkinson Ref. Co., 370 U.S. 195, 215 (1962) (Brennan, J., dissenting).

is The Court relied heavily on precedents under the Railway Labor Act, 45 U.S.C. $\$ \S$ 151-188 (1970). 398 U.S. at 251-52. See, e.g., Brotherhood of R.R. Trainmen v. Chicago River \& Ind. R.R., 353 U.S. 30 (1957), affirming the issuance of an injunction restraining a strike in violation of the statutorily imposed duty to arbitrate disputes submitted to the National Railroad Adjustment Board for resolution. The Court there concluded that the NorrisLaGuardia Act's policy of nonintervention should be accommodated with, and in effect give way to, the important federal policy of peaceful settlement of railroad labor disputes subject to NRAB procedures.

13 398 U.S. at 247. 
method of enforcing no-strike obligations-an injunction-was not available.

This last observation intimated a more general point-that the collective bargaining process as a whole is weakened by a court's refusal to order the specific performance of a contractual undertaking. Preserving the enforceability of collective bargaining agreements, of course, is a more inclusive rationale for equitable intervention than the policy favoring arbitration of labor disputes..$^{20}$ Interestingly, before the decision in Boys Markets certain lower courts had read Textile Workers Union v. Lincoln Mills, ${ }^{21}$ where the Supreme Court specifically enforced an arbitration agreement, as authorizing broad authority to specifically enforce all provisions of collective bargaining agreements. ${ }^{22}$ These cases in effect adopted an accommodation of section 301 and the Norris-LaGuardia Act that would permit injunctions to enforce all union no-strike obligations, rendering the anti-injunction provisions of section 4 virtually inapplicable in section 301 actions.

Justice Brennan, however, stressed that the holding of Boys Markets was a "narrow one" that did not undermine the vitality of the Norris-LaGuardia Act. ${ }^{23}$ Equitable intervention was authorized only where the work stoppage concerned an issue resolvable in arbitration. Moreover, injunctive relief was not necessarily appropriate "in every case of a strike over an arbitrable grievance." 24 Quoting from his dissent in Sinclair, Justice Brennan listed the following principles to guide courts in issuing labor injunctions:

A District Court entertaining an action under $\S 301$ may not grant injunctive relief against concerted activity unless and until it decides that the case is one in which an injunction would be appropriate despite the Norris-LaGuardia Act. When a strike is sought to be enjoined because it is over a grievance which both parties are contractually bound to arbitrate, the District Court may issue no injunctive order until it first holds that the contract does have that effect; and the employer should be ordered to arbitrate, as a condition of his obtaining

20 All contract breaches, whether or not they could be resolved by the arbitration provisions of the governing agreement, would be subject to equitable relief under this formulation.

21353 U.S. 448 (1957).

22 See, e.g., Teamsters Local 795 v. Yellow Transit Freight Lines, Inc., 282 F.2d 345 (10th Cir. 1960), rev'd, 370 U.S. 711 (1962); Chicago \& I11. Midland Ry. v. Brotherhood of R.R. Trainmen, 315 F.2d 771 (7th Cir. 1963), vacated with instructions to dismiss as moot, 375 U.S. 18 (1963) (accommodating the Norris-LaGuardia Act with the Railway Labor Act).

23398 U.S. at 253.

2" Id. at 254 . 
an injunction against the strike. Beyond this, the District Court must, of course, consider whether issuance of an injunction would be warranted under ordinary principles of equity-whether breaches are occurring and will continue, or have been threatened and will be committed; whether they have caused or will cause irreparable injury to the employer; and whether the employer will suffer more from the denial of an injunction than will the union from its issuance. ${ }^{25}$

Clearly, Boys Markets did not establish a general specific performance remedy, but only relaxed the strictures of the NorrisLaGuardia Act for a limited class of breach-of-contract strikes. However, the Supreme Court's next full decision attempting to accommodate section 301 with the anti-injunction provisions significantly expanded the availability of Boys Markets relief.

\section{Gateway Coal: Extension of the Compromise}

Gateway Coal Co. v. United Mine Workers ${ }^{26}$ contained, at least implicitly, elements of a general injunction remedy for the breach of union no-strike obligations. The Supreme Court upheld an order enjoining a strike alleged to be in breach of contract and ruled that any dispute over the scope of the no-strike obligation should be resolved in arbitration.

The strike grew out of a safety dispute involving the failure of three foremen in a coal mine to report reduced air flow caused by the collapse of a ventilation structure. At the union's insistence, the foremen were suspended from work. The state department of environmental resources, after investigating the incident, determined that the company should be allowed to return the foremen to work, even though criminal charges were pending against them. When the company reinstated two of the foremen (the third had retired in the interim), the miners walked off the job. ${ }^{27}$

The union rejected the company's offer to arbitrate the dispute over the continued use of the two foremen. Although the collective bargaining agreement between the parties did not contain a nostrike clause, the grievance-arbitration provisions were unusually broad, subjecting to arbitration not only differences over the mean-

${ }^{25}$ Id., quoting Sinclair Ref. Co. v. Atkinson, 370 U.S. 195, 228 (1962) (Brennan, J., dissenting).

${ }^{24} 414$ U.S. 368 (1974). See generally Atleson, Threats to Health and Safety: Employee Self-Help Under the NLRA, 59 MinN. L. REv. 647 (1975).

${ }^{27}$ The two who had been reinstated ultimately pleaded nolo contendere to charges of falsification of records and were fined $\$ 200$ each. 414 U.S. at 72. 
ing of the agreement but also disagreements about matters "not specifically mentioned" in the contract and "any local trouble of any kind . . . at the mine." ${ }_{28}$ Only disputes that could be described as "national in character" were exempted. ${ }^{2 \theta}$

The Supreme Court reversed the court of appeals and affirmed the district court's issuance of an injunction that restrained the strike, required arbitration of the dispute over the alleged safety hazard involved in the continued use of the foremen, and ordered the suspension of the foremen pending the arbitrator's decision. The Court's analysis of the propriety of breach-of-contract strike injunctions, however, shifted from that employed in Boys Markets. The opinion in Boys Markets did not place particular weight on the existence of the express no-strike clause governing the parties: indeed, the Court's strong emphasis on the policy favoring labor arbitration could be read to mean that the injunction restraining the strike was in furtherance of the arbitration provisions of the parties' agreement, rather than in the nature of enforcement of the no-strike clause. ${ }^{30}$

Justice Powell's opinion for the majority in Gateway Coal reiterated the Court's high regard for the policy favoring labor arbitration, even in the context of disputes over safety conditions; ${ }^{31}$ but the main thrust of the opinion dealt with the nature of the no-strike obligation, viewed as critical to the district court's authority to award injunctive relief. The Mine Workers had forcefully contended that because the bargaining agreement did not contain an express no-strike clause and, in fact, provided that express no-strike clauses in prior agreements were "rescinded, cancelled, abrogated and made null and void," ${ }^{32}$ the district court was deprived of any author-

Id. at 374 n.6.

Id. at 375 n.7.

30 Even if management is not encouraged by the unavailability of the injunction remedy to resist arbitration agreements, the fact remains that the effectiveness of such agreements would be greatly reduced if injunctive relief were withheld. Indeed, the very purpose of arbitration procedures is to provide a mechanism for the expeditious settlement of industrial disputes without resort to strikes, lockouts, or other self-help measures. This basic purpose is obviously largely undercut if there is no immediate, effective remedy for those very tactics that arbitration is designed to obviate.

398 U.S. at 249.

${ }^{31}$ The court of appeals had embraced the proposition that national labor policy affirmatively disfavors arbitration of safety disputes, and it questioned whether labor arbitrators might be too grudging in appreciating the interest of workers in safety. $466 \mathrm{~F} .2 \mathrm{~d}$ at $1157,1159-$ 60. Justice Powell's opinion regarded the trial court's order requiring the suspension of the two foremen pending arbitration as effectively eliminating any safety issue in the case. 414 U.S. at $387-88$.

${ }^{32}$ National Bituminous Coal Wage Agreement of 1968, Miscellaneous Section, I 1, quoted in 414 U.S. at 384 n.15. 
ity to enjoin a strike, whether in derogation of an agreement to arbitrate or not. Justice Powell responded to this contention by implying an obligation not to strike from the contractual commitment to submit disputes to arbitration, ${ }^{33}$ invoking the old chestnut that "a no-strike obligation, express or implied, is the quid pro quo for an undertaking by the employer to submit grievance disputes to the process of arbitration." 34

The centrality of the no-strike obligation, even if implied, to the Court's view of the foundation of Boys Markets injunctions is demonstrated by Justice Powell's conclusion that the authority to issue an injunction "depends on whether the union was under a contractual duty not to strike." 35 Justice Powell observed that in most cases the agreement to arbitrate and the obligation not to strike would be coterminous, but he suggested that they are "analytically distinct" issues. ${ }^{36}$ Thus, the parties could agree specifically to negate a nostrike obligation, leaving only an agreement to arbitrate-which would not be sufficient to authorize a Boys Markets injunction against a breach-of-contract strike. ${ }^{37}$

The importance of the scope of the no-strike obligation to a court's authority to issue injunctive relief is further demonstrated by Justice Powell's analysis of section 502 of the Labor Management Relations Act, ${ }^{38}$ which permits refusal to work in the face of abnormally dangerous working conditions. Although the majority suggested that the section 502 privilege was inapplicable on the facts of Gateway Coal since the allegation of abnormally dangerous conditions was supported by no more than the subjective judgment of the employees, Justice Powell stated in dictum that the proper invocation of section 502 by the presentation of objective evidence would have created an exception to an express or implied no-strike obligation and that this exception would have deprived the trial court of the authority to issue a Boys Markets injunction. ${ }^{39}$

Furthermore, the Court interpreted the contract in Gateway

33 The Court relied on Local 174, Teamsters v. Lucas Flour Co., 369 U.S. 95 (1962), which had established that in a $\S 301$ damage action a no-strike obligation could be implied from an agreement to submit disputes to arbitration. For criticism of this decision, and for its implications for the principle of freedom of contract in development of $\S 301$ law, see $H$. Weluington, Labor and the Legal Process $112-19$ (1968).

It 414 U.S. at 382, quoting Boys Mkts., Inc. v. Retail Clerks Local 770, 398 U.S. 235, 248 (1970), citing Textile Workers Union v. Lincoln Mills, 353 U.S. 448, 455 (1957).

ss 414 U.S. at 380.

3 Id. at 382 .

rId.

ss 29 U.S.C. § $143(1970)$.

33414 U.S. at 385. 
Coal to provide that any dispute over the scope of the no-strike obligation was to be resolved under the broad arbitration provisions in the governing bargaining agreement. The court of appeals, reversing the district court, had found that a contractual provision permitting a local mine safety committee to remove mine workers from an unsafe area had been substantially invoked-creating an express exception to the no-strike obligation. The Supreme Court found this interpretation doubtful, and ruled that whether these procedures had been properly invoked by the Mine Workers was "a substantial question of contractual interpretation" 40 that should have been resolved under the agreement's dispute settlement provisions. ${ }^{41}$

In sum, Gateway Coal expanded the "limited" category of cases in which labor injunctions will be deemed appropriate. First, even in the absence of an express no-strike clause, the presence of final and binding grievance-arbitration procedures in the bargaining agreement may give rise to an implied no-strike obligation authorizing a court to enjoin a strike. Second, disputes arising over the scope or application of the express or implied no-strike obligation are to be resolved under the grievance-arbitration procedures which the parties will be directed to utilize as part of the comprehensive relief ordered. ${ }^{42}$

to Id. at 384.

"In what may be an alternative holding, the Court appeared to affirm the district court's finding that the procedures had not been properly invoked. Id. at 383 . Even after Gateway the Third Circuit remains of the view that the trial court has the authority to determine whether the UMW contractual provision permitting a local mine safety committee to remove workers from an unsafe area has been properly invoked. In Jones \& Laughlin Steel Corp. v. UMW, 519 F.2d 1155 (3d Cir. 1975), the panel majority determined that a proper invocation of the provision by the mine safety committee created an exception to the implied no-strike obligation in the UMW agreement, depriving the trial court of authority to issue an injunction requiring employees to work in those areas designated as imminent dangers by the committee. Judge Rosenn dissented in part on the ground that further factual development in the trial court was necessary because the record did not demonstrate conclusively that the mine safety committee had properly invoked the no-strike exception. Id. at 1159-60 (Rosenn, J., concurring and dissenting).

12 Justice Douglas filed the lone dissent. 414 U.S. at 388-94. He agreed with the majority that in injunction suits an obligation not to strike could be implied from an agreement to arbitrate. Id. at 391 . In his view, however, the parties' agreement had specifically reserved to the union the unrestricted right to close the mine because of safety hazards, id. at 389 , and $\S$ 502 negated any presumption of arbitrability with respect to safety disputes. Id. at 391-92. He concluded that even if the parties' agreement had specifically, or by operation of the arbitrability presumption, required submission of safety disputes to arbitration, the comprehensive regulatory scheme afforded by the Federal Coal Mine Health and Safety Act, 30 U.S.C. $\$ \S 801-960$ (1970), preempted all agreements to arbitrate mine safety disputes and excluded arbitration from any role in the regulation of mine safety. 414 U.S. at 394 . With this position, compare Justice Powell's opinion for the Court in Alexander v. Gardner-Denver Co., 415 U.S. 36 (1974), issued shortly after Gateway, where the Court ruled that prior 


\section{Buffalo Forge: Retreat from the Expansionist Remedy}

In Buffalo Forge Co. $v$. United Steelworkers, ${ }^{43}$ the Supreme Court restricted Gateway Coal's authorization of a strike injunction pending arbitral resolution of the scope of the no-strike obligation. Reverting to the principal rationale of the Boys Markets accommodation of section 301 and the Norris-LaGuardia Act-furtherance of arbitration as a means of settling labor disputes-the Court determined that more than a dispute about the application of a no-strike obligation to a particular work stoppage is required to justify injunctive relief. In addition, the strike must have been precipitated by a dispute between the parties that is itself arbitrable.

Two locals of the United Steelworkers Union represented and negotiated collective bargaining agreements on behalf of the production and maintenance employees (PM employees) of the Buffalo Forge Company. ${ }^{44}$ The bargaining agreement of the PM employees contained a no-strike clause prohibiting "strikes, work stoppages or interruption or impeding of work," 45 and established procedures for the adjustment of grievances, which were defined to include "differences ... between the [employer] and any employee... . as to the meaning and application" of the agreement's provisions and "any trouble of any kind . . . in the plant." ${ }_{48}$ With respect to grievances involving the "meaning and application" of the agree-

arbitration of an employment discrimination claim does not preclude, and may be denied any and all weight in, a subsequent action brought pursuant to Title VII of the Civil Rights Act of 1964, 42 U.S.C. $\$ \S 2000 \mathrm{e}$ to $2000 \mathrm{e}-17$ (1970 \& Supp. V 1975).

${ }^{43} 428$ U.S. 397 (1976).

1The statement of facts in the text is derived from Justice White's opinion for the Court, supplemented by the opinion of the district court, 386 F. Supp. 405, 407-09 (W.D.N.Y. 1974), and the opinion of the court of appeals, 517 F.2d 1207, 1209 (2d Cir. 1975).

is Section 14.b. of each collective bargaining agreement provided:

There shall be no strikes, work stoppages or interruption or impeding of work. No Officers or representatives of the Union shall authorize, instigate, aid or condone any such activities. No employee shall participate in any such activity. The Union recognizes its possible liabilities for violation of this provision and will use its influence to see that work stoppages are prevented. Unsuccessful efforts by Union officers or Union representatives to prevent and terminate conduct prohibited by this paragraph, will not be construed as "aid" or "condonation" of such conduct and shall not result in any disciplinary actions against the Officers, committeemen or stewards involved.

428 U.S. 399 n.1 (1976).

1" Section 26 of the agreements provided:

Should differences arise between the [employer] and any employee covered by this Agreement as to the meaning and application of the provisions of this Agreement, or should any trouble of any kind arise in the plant, there shall be no suspension of work on account of such differences, but an earnest effort shall be made to settle such differences immediately [in the following manner] ....

428 U.S. at 400. 
ment's provisions, the procedures culminated, after five successive stages, in final and binding arbitration. ${ }^{47}$

Two other Steelworkers locals represented the company's office, clerical and technical employees (OCT employees). Having failed to negotiate a first collective bargaining agreement with the company covering the OCT employees, the Steelworkers and the OCT employee locals struck and established picket lines at the company's three Buffalo facilities. The company attempted to forestall a PM employee sympathy work stoppage by offering to arbitrate any dispute between the PM employees and the company, but the offer was rejected. When the PM employees refused to cross the OCT picket lines, stopping work at all three plants, the company filed a section 301 suit seeking an injunction and damages from the locals representing the PM employees.

The company argued that the refusal to cross the picket lines created an arbitrable dispute as to whether the no-strike clause in the agreement had been breached, and that Boys Markets therefore authorized the court to halt the work stoppage pending submission of the dispute to the grievance-arbitration procedure. ${ }^{48}$ The trial court rejected this contention, reasoning that the exception to the anti-injunction provisions of the Norris-LaGuardia Act created by Boys Markets was a "narrow" one, arising, in the words of Boys Markets itself, "[w]hen a strike . . . sought to be enjoined . . . is over a grievance which both parties are contractually bound to arbitrate . . . "49 Following the lead of the Fifth Circuit in Amstar Corp. $v$. Amalgamated Meat Cutters, ${ }^{50}$ the court found that because

${ }^{17}$ See note 52 infra.

13 Before the trial court, the company also contended that the work stoppage was caused by a dispute with the PM employee locals regarding the assignment of truck driving duties to PM employees during the OCT employees' strike. The district judge found that the work stoppage was caused solely by the instructions of the Steelworkers not to cross OCT picket lines, 386 F. Supp. at 408-09, and the company did not seek to disturb this finding on appeal. 517 F.2d at 1211 n.7.

1 386 F. Supp. at 409, quoting Boys Mkts., Inc. v. Retail Clerks Local 770, 398 U.S. at 254, quoting Sinclair Ref. Co. v. Atkinson, 370 U.S. 195, 228 (Brennan, J., dissenting) (emphasis added).

so 468 F.2d 1372 (5th Cir. 1972), rev'g 337 F. Supp. 810 (E.D. La. 1972). In Amstar, members of the International Longshoremen's Association on strike against the company established a picket line at the company's Chalmette, Louisiana refinery. Company production and maintenance employees at that location were represented by the Meat Cutters, and had negotiated a collective agreement prohibiting strikes and providing a grievancearbitration procedure for the resolution of "differences and complaints." 337 F. Supp. at 813. The trial court ordered the parties to arbitrate their "dispute" over the application of the nostrike prohibition to picket line respect, and issued an injunction restraining refusals to cross the line. The Fifth Circuit reversed, reasoning that one of the core prerequisites of the Boys Markets formula for obtaining injunctive relief was that "the strike must be 'over' an arbitra- 
the only dispute between the company and the PM employees was the propriety of the work stoppage itself, there was no strike "over" an arbitrable issue. The dispute that had caused the strike, the court reasoned, was between the company and the OCT employees, a matter clearly not cognizable under the bargaining agreement of the PM employees. The court of appeals affirmed.51

Buffalo Forge actually presented a stronger case for denying injunctive relief than Amstar. Although the grievance-arbitration procedure in Buffalo Forge permitted both the Company and the union to appeal from the fifth stage of the grievance procedure to arbitration, ${ }^{52}$ only the employees were permitted to file "grievances," and only the employees and the union were permitted to appeal grievances to higher stages within the grievance procedure.53 Such one-sided "employee-oriented" grievance-arbitration procedures are usually negotiated at the insistence of employers, to insure that their breach of contract claims will not be subject to binding contract arbitration but will be cognizable only in court actions. ${ }^{54}$ Boys Markets relief had been denied by some courts in

ble grievance" and "both parties must be contractually bound to arbitrate the underlying grievance which caused the strike." 468 F.2d at 1373 (emphasis added). The court of appeals concluded that the refusal to cross the ILA picket line was itself the cause of the dispute between the parties and could not, therefore, be the basis of injunctive relief. The Fifth Circuit reaffirmed its Amstar reasoning in United States Steel Corp. v. UMW, 519 F.2d 1236 (5th Cir. 1975). For other cases following Amstar's interpretation of Boys Markets, see Plain Dealer Publishing Co. v. Cleveland Typographical Union No. 53, 520 F.2d 1220 (6th Cir. 1975), cert. denied, 428 U.S. 909 (1976); Carnation Co. v. Teamsters Local 949, 86 L.R.R.M. 3012 (S.D. Tex. 1974); Pilot Freight Carriers, Inc. v. Local 560, Int'l Bhd. of Teamsters, 373 F. Supp. 19 (D.N.J. 1974). For pre-Amstar district court rulings embracing the same interpretation, see Ourisman Chevrolet Co. v. Automotive Lodge 1486, 77 L.R.R.M. 2084 (D.D.C. 1971); Simplex Wire \& Cable Co. v. Local 2208, IBEW, 314 F. Supp. 885 (D.N.H. 1970); General Cable Corp. v. IBEW Local 1644, 331 F. Supp. 478 (D. Md. 1971).

s 517 F.2d 1207 (2d Cir. 1975).

32 Section 32 provided:

Sixth. In the event the grievance involves a question as to the meaning and application of the provisions of this Agreement, and has not been previously satisfactorily adjusted, it may be submitted to arbitration upon written notice of the Union or the Company ... . The arbitrator shall not have the power to add to, to disregard, or modify any of the terms and conditions of this Agreement. The decision of the arbitrator shall be binding upon the parties.

Appendix to Briefs of the Parties, at 17, Buffalo Forge Co. v. United Steelworkers, 517 F.2d 1207 (2d Cir. 1975).

ss Section 27 of the bargaining agreement provided that grievances, as defined in section 26, note 46 supra, could be settled "[f]irst . . . . [b]etween the aggrieved employee and the foreman of the department involved. . . ." Subsequent sections of the contract permitted appeals to higher stages of the procedure by an aggrieved employee or a member of the union's grievance committee. Step 5 of the procedure was the final prearbitration stage. Id.

* In Atkinson v. Sinclair Ref. Co., 370 U.S. 238 (1962), the Supreme Court ruled that where an employer was denied access to a grievance-arbitration procedure because the procedure was "employee oriented," it was error for the trial court to issue a stay of the employer's 
cases involving "employee-oriented" grievance procedures on the ground that the contractual exclusion of employer claims from the grievance procedure precludes a court from ordering arbitration in conjunction with a strike injunction. ${ }^{55}$ This basis for denying injunctive relief did not exist in Amstar, where the employer was permitted by the contract to initiate the grievance procedure. ${ }^{56}$ Neither the trial judge nor the court of appeals in Buffalo Forge, however, relied on this distinction in denying injunctive relief. ${ }^{57}$

$\S 301$ damage action alleging union breach of contract pending submission of the employer's damage claim to an arbitrator. Accord, Faultless Div. v. Local 2040, Int'l Ass'n of Machinists, 513 F.2d 987 (7th Cir. 1975); Ed Friedrich v. Local 780, IUE, 515 F.2d 225 (5th Cir. 1975); Affiliated Food Distribs., Inc. v. Local 229, Int'l Bhd. of Teamsters, 483 F.2d 418 (3d Cir. 1973), cert. denied, 415 U.S. 916 (1974); but see Drake Bakeries, Inc. v. Local 50, American Bakery Workers, 370 U.S. 254 (1962) (stay of damage action pending arbitration affirmed because employer had right to initiate contract's grievance procedure as well as appeal to arbitration regarding its claim for damages arising out of union breach of no-strike clause). See also Reid Burton Constr., Inc. v. Carpenters District Council, 535 F.2d 598 (10th Cir. 1976); Meat Cutters Local 195 v. Cross Bros. Meat Packers, Inc., 518 F.2d 1113 (3d Cir. 1975); Controlled Sanitation Corp. v. District 128, Int'l Ass'n of Machinists, 524 F.2d 1324 (3d Cir. 1975); Blake Constr. Co. v. Laborers' Int'l Union, 511 F.2d 324 (D.C. Cir. 1975).

ss See Atlantic Richfield Co. v. Oil Workers Int'l Union, 447 F.2d 945, 946 n.1 (7th Cir. 1971); Hormel \& Co. v. Local P-31, Meat Cutters, 349 F. Supp. 785 (N.D. Iowa 1972); Stroehmann Co. v. Local 427, Confectionery Workers, 315 F. Supp. 647 (M.D. Pa. 1970). But see Monongahela Power Co. v. Local 2332, IBEW, 484 F.2d 1209 (4th Cir. 1973).

ss See Amstar Corp. v. Amalgamated Meat Cutters, 337 F. Supp. 810, 813-14 (E.D. La. 1972).

${ }^{37}$ The Amstar rationale for denying Boys Markets relief against picket line respect arguably in violation of a no-strike obligation was rejected in a variety of factual contexts by the Third, Fourth, and Eighth Circuits, with the Seventh Circuit initially rejecting but subsequently expressing qualified approval. See Valmac Indus., Inc. v. Food Handlers Local 425, 519 F.2d 263 (8th Cir. 1975), vacated and remanded, 428 U.S. 906 (1976); Associated Gen. Contractors v. Operating Eng'rs Local 49, 519 F.2d 269 (8th Cir. 1975); NAPA Pittsburgh, Inc. v. Automotive Chauffeurs Local 926, 502 F.2d 321 (3d Cir.) (en banc), cert. denied, 419 U.S. 1049 (1974), noted in 88 Harv. L. Rev. 463 (1974); Wilmington Shipping Co. v. Longshoremen's Local 1426, 86 L.R.R.M. 2846 (4th Cir.), cert. denied, 419 U.S. 1022 (1974); Pilot Freight Carriers, Inc. v. International Bhd. of Teamsters, 497 F.2d 311 (4th Cir.), cert. denied, 419 U.S. 869 (1974); Monongahela Power Co. v. Local 2332, IBEW, 484 F.2d 1209 (4th Cir. 1973).

The Seventh Circuit's opinion in Inland Steel Co. v. Local 1545, UMW, 505 F.2d 293 (7th Cir. 1974), spawned a line of cases which represented the broadest extension of Boys Markets injunctive relief. Construing the provisions of the Bituminous Coal Wage Agreement which did not contain a no-strike clause, these decisions ruled that unusually.broad grievancearbitration provisions, similar to those in Gateway Coal, subjecting to arbitration "disputes about matters not specifically mentioned in this agreement" and "any local trouble of any kind aris[ing] at the mine," $i d$. at 297 n.5, permitted the implication of a no-strike obligation. This implied obligation formed the basis for an injunction prohibiting picket line respect pending an arbitral determination of the work stoppage's permissibility under the bargaining agreement. See Island Creek Coal Co. v. UMW Local 998, 507 F.2d 650 (3d Cir.), cert. denied, 423 U.S. 877 (1975); Armco Steel Corp. v. UMW, 505 F.2d 1129 (4th Cir. 1974), cert. denied, 423 U.S. 877 (1975). In Hyster Co. v. Independent Towing \& Lifting Machine Ass'n, 519 F.2d 89 (7th Cir. 1975), cert. denied, 428 U.S. 910 (1976), however, the Seventh Circuit confined Inland Steel to its precise facts. Citing Amstar with apparent approval, the court vacated an 
Justice White's opinion for the Supreme Court majority upholding the denial of injunctive relief relied in part on a determination that the union's work stoppage had not "deprived the employer of his bargain." 58 No analysis of the "employer's bargain" in terms of the right of access to the grievance-arbitration mechanism was undertaken, however. Although the employer's only access to the grievance-arbitration mechanism was by appeal to arbitration after exhaustion of the "employee-oriented" grievance procedure, Justice White declared that " $t]$ he employer ... was entitled to invoke the arbitral process to determine the legality of the sympathy strike and to obtain a court order requiring the Union to arbitrate if the Union refused to do so." ${ }^{59}$ But under the parties' contract, this statement would be accurate only if an "aggrieved" employee or the union had initiated the grievance procedure and had appealed a claim of contract breach to the final step of the grievance process, or if the union had waived the prearbitration grievance procedure.

Justice White's determination that the union was required to arbitrate the employer's breach-of-contract claim did not, however, entitle the employer to injunctive relief pending arbitration. Agreeing with the analysis in Amstar, the Court majority concluded that the "narrow" holding in Boys Markets authorized prearbitration injunctive relief against a breach of contract strike only when the strike was "over," or precipitated by, an otherwise arbitrable dispute between the parties. ${ }^{\circ 0}$ The picket line respect and sympathy strike at issue "had neither the purpose nor the effect of denying or evading an obligation to arbitrate," of concern of Boys Markets. Nevertheless, the Court ordered the union to arbitrate the dispute over the scope of the no-strike clause, and ruled that if the arbitrator determined that the sympathy strike was in breach of contract, and the union continued its work stop-

injunction barring a work stoppage caused by picket line respect, and concluded that respect for another union's picket line did not raise an arbitrable issue under the contract and was not, in any event, prohibited by the relevant agreement's express no-strike clause.

Post-Boys Markets decisions under the Railway Labor Act also permitted injunctive relief against refusals to cross picket lines. See, e.g., Northwest Airlines, Inc. v. Machinists Lodge 143, 442 F.2d 246 (8th Cir. 1970) (contract contained express no-strike clause); Northwest Airlines, Inc. v. Air Line Pilots Ass'n, 442 F.2d 246 and 251 (8th Cir. 1970 and 1971), cert. denied, 404 U.S. 371 (1971) (contract did not contain express no-strike clause); Puerto Rico Int'l Airlines v. Air Line Pilots Ass'n, 86 L.R.R.M. 3189 (D.P.R. 1974); Ozark Air Lines, Inc. v. Airline Pilots Ass'n, 361 F. Supp. 198 (E.D. Mo. 1973).

ss 428 U.S. at 408 (1976).

s) Id. at 405 . Later the majority stated, "Concededly, that issue was arbitrable." Id. at 410.

id. at 403.

'I Id. at 408. 
page, a court could enforce the arbitrator's award by enjoining the strike. Such an injunction would be an enforcement of the arbitrator's award, making it consonant with the policy favoring labor arbitration. ${ }^{62}$

Justice White suggested that authorizing prearbitration injunctive relief where the only disputed issue is the permissibility of the work stoppage itself would impair the federal policy favoring labor arbitration of contract disputes. The courts in such cases would usurp arbitration by delving into the merits of breach of contract strike claims in preliminary injunction hearings. ${ }^{63}$ Since the parties do not, in conventional grievance-arbitration clauses, contract for a "judicial preview of the facts and the law," that to permit judicial intervention would "eviscerate" the use of contractual procedures. ${ }^{65}$ Related to this concern, and perhaps more important to the Court's determination to deny injunctive relief, was its fear that expanding Boys Markets injunctions to encompass specific enforcement of all no-strike obligations would flood the already heavily burdened federal courts with "massive" preliminary injunction litigation. ${ }^{66}$

Finally, Justice White's opinion argued that Congress' refusal to repeal the Norris-LaGuardia Act when it enacted section 301 demonstrated that there was no general federal anti-strike policy embodied in section $301 .^{67}$ Thus, it would be inappropriate to interpret section 301 to allow general injunctive enforcement of no-strike obligations, without regard to protecting the arbitration process. In this connection the Court apparently rejected any further expansion of Boys Markets relief beyond the facts in Gateway Coal. Although the Court in Gateway Coal had specifically enforced an implied nostrike obligation and had ruled that the issue concerning the scope of the no-strike obligation should have been submitted to arbitration, such relief was appropriate, according to Justice White, only because the strike itself had been precipitated by a dispute arbitra-

2 Id. at 405, citing United Steelworkers of America v. Enterprise Wheel \& Car Corp., 363 U.S. 593 (1960); see New Orleans Steamship Ass'n v. General Longshore Workers Local 1418, 389 F.2d 369 (5th Cir.), cert. denied, 393 U.S. 828 (1968).

s 428 U.S. at $410,410-12$.

of Id. at 412 .

os Id.

co Id. at 411 n.12. The Court noted that more than $21,000,000$ workers were covered by 150,000 collective bargaining agreements, but it did not indicate how or why that fact would result in "massive" preliminary injunction litigation.

"7 Id. at 409. Justice White cited the dissenting opinion in Sinclair Ref. Co. v. Atkinson, 370 U.S. 195, 228 (1962) (Brennan, J., dissenting), which was subsequently embraced in Boys Markets. 
ble under the contract. In so limiting Gateway Coal, Justice White's opinion declared, in dictum, that in the absence of an express nostrike clause, an obligation not to engage in sympathy strikes or respect for the picket lines of other unions would not be implied from the mere existence of mandatory grievance-arbitration provisions. ${ }^{88}$

Justice Steven's dissenting opinion contended that the majority's literal application of the Norris-LaGuardia Act conflicted with the policy of that statute, the policy of section 301, the prior opinions of the Court accomodating the two statutory provisions, and the favored policy of promoting labor arbitration. ${ }^{89}$ The dissenters, however, refused to embrace the full logical conclusion their premises required. Injunctions enforcing no-strike clauses would be ordered, in their analysis, only when the union's strike "clearly" violated a contractual no-strike clause. ${ }^{70}$

A review of the policy framework of the Norris-LaGuardia Act convinced the dissenters that the purpose of the Act was to promote collective bargaining by preventing the often hostile federal courts from interfering with the right to organize and choose bargaining representatives. ${ }^{71}$ Because "experience during the decades since the Norris-LaGuardia Act was passed has dissipated any legitimate concern about the impartiality of federal judges in disputes between labor and management," 72 the dissenters viewed injunctions enforcing collective bargaining agreements as not impinging on the central concerns of the Act. The legislative history of section 301 reinforced this conclusion because Congress, by stating in the Conference Report that the enforcement of bargaining agreements should be left to "the usual processes of law," ${ }^{3}$ indicated its intention to allow injunctions in enforcement of bargaining agreements.

Justice Stevens advanced two arguments attacking the majority's premise that an injunction against picket line respect or a sympathy strike would not serve the policy favoring labor arbitra-

cs Id. at 408. The Court, therefore, directly disapproved the implication of such an obligation in Inland Steel Co. v. Local 1545, UMW, 505 F.2d 293 (7th Cir. 1974), and the apparent acquiescence in this line of reasoning by the courts of appeals in Buffalo Forge and Amstar. Id. at 408-09 n.10. Justice Stevens's dissenting opinion agreed with the majority's dictum. Id. at $425 \mathrm{n} .17$.

" 428 U.S. at 413 (Stevens, J., dissenting). Justices Brennan, Marshall, and Powell joined the dissenting opinion.

30 Id. at 426.

"Id. at $415-16 \mathrm{nn} .6$ \& 7 .

72 Id. at 432 .

${ }^{73}$ Id. at 420, 422, quoting Textile Workers Union v. Lincoln Mills, 353 U.S. 448, 452 (1957) (Douglas, J.), quoting H.R. CoNf. REP. No. 510, 80th Cong., 1st Sess. 42 (1947). 
tion. First, while conceding that respect for a picket line or a sympathy strike does not directly frustrate the arbitration process, the dissenters contended that the lack of a specific performance remedy "frustrate[s] the more basic policy of motivating employers to agree to binding arbitration"74 by weakening the bargained-for assurance of uninterrupted production during the term of the agreement. Second, and more important, the dissent could find no justification for the majority's authorizing injunctions to enforce an arbitrator's decision banning sympathy work stoppages while refusing such relief prior to the arbitrator's award..$^{75}$ In neither situation is the strike technically "over" an arbitrable issue ${ }^{76}$ and the dissent noted that the same reasons that justify an injunction requiring the parties to obey an arbitrator's determination that a strike is in violation of a no-strike clause also "justify an injunction against a strike that would impair his ability to reach a decision."77

Concern that a court issuing a breach-of-contract strike injunction would usurp the role of the labor arbitrator in construing the contract, however, prompted the dissenters to withdraw from endorsing an unrestricted injunction remedy. To ensure proper respect for the greater expertise of labor arbitrators relative to federal judges, and the appropriate relationship between courts and arbitrators, Justice Stevens would permit equitable intervention only when there was "convincing evidence that the strike is clearly within the no-strike clause,"78 and, apparently, when issues regarding the scope of the no-strike clause are "clearly arbitrable" under the contract. ${ }^{79}$

As the author of the student note espousing the "clearly within the no-strike clause" standard adopted by the dissent commented, injunctions under this standard "will be issued rarely, although in many cases the strike will eventually be found illegal." ${ }^{80}$ In practice,

"Id. at 424.

${ }^{75}$ Id. at $424-26$.

${ }^{76}$ Id. at 413 n.2.

$\pi I d$. at 425 .

78 Id. at 431 .

79 It is not necessary to hold that an injunction may issue if the scope of the nostrike clause is not a clearly arbitrable issue. If the agreement contains no arbitration clause whatsoever, enforcement of the no-strike clause would not promote arbitration by encouraging employers to agree to an arbitration clause in exchange for a no-strike clause. Furthermore, even if the agreement contains an arbitration clause, but the clause does not clearly extend to the question whether a strike violates the agreement, the parties' commitment to enforcement of the no-strike clause through enforcement of the arbitrator's final decision also remains unclear.

Id. at $426-27$ n. 20 .

Note, The Applicability of Boys Markets Injunctions to Refusals to Cross a Picket 
therefore, the majority and dissenting opinions would not produce substantially different results. If the dissenter's standard prevailed, most trial judges, advised by Justice Stevens that they are not as expert as labor arbitrators in breach of labor contract matters, would probably be quite reluctant to find "convincing evidence" of a "clear" contract violation. Astute union counsel would have little difficulty pointing to ambiguities in contractual language notorious for its lack of precision. ${ }^{81}$ Nor would the frequency of intervention increase over time through the development of a body of precedent. Even if a particular no-strike clause were judicially determined to "clearly" bar a sympathy strike or picket line respect, this finding would probably have little application outside the particular adjudication. Sympathy strikes and picket line respect rarely take the same form or follow the same pattern, and a clause "clearly" prohibiting a specific form of activity may well be ambiguous when applied to another fact pattern or to the same fact pattern in a different collective bargaining relationship. Moreover, questions about the scope of a "clear" clause may be "clearly arbitrable" in one collective bargaining relationship but not in another, and under Justice Stevens's standard ambiguity on the arbitrability of no-strike issues is also a ground for refusing injunctive relief. Therefore, few circumstances in which both the no-strike and arbitrability issues are "clear" will arise.

A common theme unites the majority and dissenting opinions in Buffalo Forge in their withdrawal from the expanded remedy established in Gateway Coal: when the sole dispute between labor and management concerns the permissibility of a work stoppage under a contract, the distrust of federal judges embodied in the Norris-LaGuardia Act requires that federal courts be precluded from prearbitration equitable intervention entirely (majority) or in most, if not all, circumstances (minority). An assessment of this

Line, 76 Colum. L. Rev. 113, 138 (1976). The author of this note cited Stokely-Van Camp, Inc. v. Thacker, 394 F. Supp. 715 (W.D. Wash. 1975), as authority for the proposal and justified this thesis by contending that the employer had an adequate remedy, namely, assuring that the contract clearly indicates what conduct is prohibited. "Thus, the employer simply bears the burden of sloppy draftsmanship." 76 CoLum. L. REv. at 140 .

s! [T] here is never, of course, enough time to do an impeccable job of draftsmanship after substantive agreement is reached-apart from the hazard that such an effort might uncover troublesome disagreement. Though the subject matter is complex and the provisions intricate, the language must nevertheless be directed to laymen whose occupation is not interpretation .... .

Shulman, Reason, Contract and Law in Labor Relations, 68 Harv. L. Rev. 999, 1004 (1955). An appreciation of the complexity, intricacy and variety of no-strike clauses may be gained by referring to BNA, Collective Bargaining Negotiations and Contracts 77:1-77:2 (1975). 
distrust in light of the policy considerations behind the NorrisLaGuardia Act and section 301 follows.

IV. Specific Enforcement of No-Strike Obligations and the Accommodation of the Norris LaGuardia Act with Section 301

The Supreme Court's decision in Buffalo Forge is unsatisfactory at several levels. In justifying a retreat from further expansion of Boys Markets relief, the majority ignored the significant labor policies furthered by permitting general injunctive relief to enforce union no-strike obligations. Moreover, the concern of both the majority and the dissent about the effect of prearbitration injunctions on the proper relationship between federal courts and arbitrators was largely unfounded. Finally, in failing to recognize the employeeoriented nature of the bargaining agreement at issue, the Court may have undermined, probably unintentionally, the continued viability of a previously unquestioned line of cases dealing with damage actions under section 301 .

\section{A. Labor Law Policy and Injunctions Enforcing No-Strike Obligations}

Congress enacted section 301 out of concern over the nonenforceability of collective bargaining settlements. At common law unions often were not suable or subject to process as legal entities, and relief against breach of contract might not be obtained even if a union were properly before a court. The primary purpose of section 301 was to remedy the absence of a labor contract enforcement mechanism by ensuring that labor contracts were binding and enforceable on the parties. ${ }^{82}$

Binding and enforceable bargaining agreements serve the interests of both labor and management in day-to-day industrial relations. Most, if not all, negotiations between the parties have the collective agreement as their reference point. An enforceable agreement protects established rights and benefits, settled procedures for dealing with job disputes, and uninterrupted production. Allowing one party to breach the agreement with impunity by denying equitable relief to the other creates a strong disincentive to participate in meaningful collective bargaining. ${ }^{83}$ The institution of collective

82 S. Rep. No. 105, 80h Cong., 1st Sess. 15-18 (1947); NLRB, Legislative History of THE Labor MaNagement Relations ACt, 1947, at 421-24 (1948).

But see Local 721, United Packinghouse, Food \& Allied Workers v. Needham Packing Co., 376 U.S. 247 (1964) (holding that a union breach of a no-strike clause does not excuse an employer from adhering to the obligation to arbitrate under a collective agreement). 
bargaining, so critical to the core purposes of national labor policy and the cause of industrial peace ${ }^{84}$ is disserved by strikes in breach of contract.

The express words of the Norris-LaGuardia Act-forbidding injunctions of all strikes unless accompanied by fraud or violence-and a considerable body of commentary ${ }^{85}$ support the Supreme Court's refusal to relax the anti-injunction strictures in all breach-of-contract strikes. Moreover, many who recognized the inequity inherent in Sinclair might now contend, as they did then, that accommodation of the anti-injunction provisions with section 301 is for Congress rather than the judiciary..$^{86}$ Yet the NorrisLaGuardia Act is only one component of the regulatory design. It was responsive to the conditions of the era preceding its enactment and was adopted to deprive the federal courts of the authority to issue injunctions assisting employers in their attempts to crush union organizational drives. ${ }^{87}$ Refusing to enforce collective bargaining agreements was not one of the corrective actions envisioned by Congress. Indeed, as the dissenters in Buffalo Forge recognized, one of the fundamental goals of the Norris-LaGuardia Act was full freedom to engage in the process of collective bargaining..$^{88}$

Outside the context of section 301, the Supreme Court has found occasion to harmonize the policies of the Norris-LaGuardia Act with other statutory objectives. The Court has determined that the anti-injunction provisions must give way to the statutory dispute-resolution procedures of the Railway Labor Act, and that strike injunctions may issue when a union has breached its Railway Labor Act obligation to make and maintain agreements by the collective bargaining process. ${ }^{89}$ The Court has also required that the anti-injunction provisions be applied in a fashion not inconsistent with the fundamental concerns of the antitrust laws. ${ }^{90}$ The fact that

s See National Labor Relations Act, ch. 370, $\$ 1,49$ Stat. 449 (1935) (current version at 29 U.S.C. $\$ 141$ (1970)).

\& E.g., Bartosic, supra note 10, at 996-1001; Dunau, supra note 10, at 463; Valadeck, supra note 10, at 100; Comment, Labor Injunctions and Judge-Made Labor Law, 70 YAle L.J. 70,99 (1960).

st See, e.g., Wellington \& Albert, supra note 10, at 1566; Section of Labor RELAtions LAw, ABA, supra note 10, at 266.

" See F. Frankfurter \& N. Greene, The Labor Injunction 5-46 (1930);E. Witte, The Government In LABOR Disputes 61-82 (1932).

See Norris-LaGuardia Act $\$ 2,29$ U.S.C. $\$ 102$ (1970), quoted in 428 U.S. at 415-16 n.6 (Stevens, J., dissenting).

s Chicago \& N.W. Ry. v. United Transp. Union, 402 U.S. 570 (1971).

0 UMW v. Pennington, 381 U.S. 657 (1965); Allen Bradley v. Local 3, IBEW, 325 U.S. 797 (1945). See also Local 189, Amalgamated Meat Cutters v. Jewel Tea Co., 381 U.S. 676 (1965). For an analysis of these cases as well as the "fundamental concerns" of antitrust policy 
the policies embodied in the provisions of the Norris-LaGuardia Act have been accommodated with the Railway Labor Act and basic antitrust policy suggests that courts should not ignore the policies underlying section 301 in interpreting the scope of the antiinjunction provisions.

Injunctions enforcing union no-strike obligations comport with the general standards for equitable intervention. The harm caused to the employer by denying injunctive relief pending an expedited arbitral determination of the no-strike issue outweighs the harm to a union by granting relief for that time period. Because of the inadequacy of union treasuries and the disruptive influence of a damage action on labor relations after a strike is settled, Boys Markets itself recognized the deficiency of the employer's damage remedy for most strikes in breach of contract.91 Moreover, the traditional argument that temporary or preliminary strike injunctions may destroy the momentum of the industrial action and impose irreparable harm on the union carries less force in the context of sympathy strikes and respect for picket lines. As Justice Stevens noted in his dissent in Buffalo Forge, sympathy work stoppages do not directly benefit the participants and may well be contrary to their own best interests. ${ }^{92}$ Thus, if the right to engage in a sympathy strike is upheld by an arbitrator, it is unlikely that the time lost during the period of arbitration will substantially dampen the enthusiasm for the strike; in fact, a favorable award could increase willingness to strike by removing any shadow of illegality from the work stoppage. In these circumstances, requiring a union to forgo a strike or work stoppage, at least until an expedited arbitration determines the rights of the parties, is a relatively small price to pay for enforcing the bargaining agreement until its own dispute-resolving procedures have been given an opportunity to function.

Remedies other than injunctions are likely to be inadequate in the context of sympathy strikes or picket line respect. If the primary strike or picketing is for the purpose of improving working conditions in an established bargaining relationship, the sympathy work stoppage or picket line respect has no "recognitional or organizational" objective and is therefore not prohibited by section 8(b)(7) of the Labor Management Relations Act. ${ }^{93}$ Furthermore, section

in connection with labor matters, see Meltzer, Labor Unions, Collective Bargaining and the Antitrust Laws, 32 U. CHI. L. Rev. 659 (1965).

" 398 U.S. at 248.

92428 U.S. at 429.

${ }^{93} 29$ U.S.C. § 158(b)(7) (1970). 
$8(b)(4)(B),{ }^{94}$ the so-called "secondary boycott" provision, may not be available if the sympathy strike or picket line respect does not serve union objectives "elsewhere"95_-because other employees of the same employer are involved-or if the pressure is not for the purpose of requiring the picketed employer to cease doing business with another "person." "98 Finally, insofar as sympathy work stoppages and respect for picket lines may be characterized as arguably subject to section 7 or 8 of the National Labor Relations Act, traditional state tort remedies against nonviolent activity are preempted. ${ }^{97}$

Denying federal courts the authority to issue prearbitration injunctions enforcing no-strike obligations also runs squarely into the enigma Boys Markets was in part designed to eliminate: divergent remedies in state and federal courts, and the effective foreclosure of state equitable remedies by the availability of removal to federal court. ${ }^{98}$ Since some states allow specific performance of no-strike

" 29 U.S.C. $\S 158(\mathrm{~b})(4)(\mathrm{B})(1970)$.

is The touchstone for determining whether $\S 8(\mathrm{~b})(4)(\mathrm{B})$ has been violated is whether the pressure is aimed at the relations between the primary employer and his employees or is "tactically calculated to satisfy union objectives elsewhere." National Woodwork Mfrs. Ass'n v. NLRB, 386 U.S. 612, 644 (1967); see Houston Insulation Contractors Ass'n v. NLRB, 386 U.S. 664 (1967).

"Where roving pickets are sent to corporate divisions or subsidiaries other than the one with which the union has a dispute, or where picketing by employees at their own place of employment is involved, the picketing does not require "persons" to cease doing business. Despite corporate divisional or subsidiary structure only one "person" exists for the purposes of \& 8(b)(4)(B). But see Packinghouse Employees Local 616, 203 N.L.R.B. 645 (1973); Local 235, Int'l Union of Lithographers, 187 N.L.R.B. 490 (1971); Local 810, Steel Fabricators \& Warehousers, 189 N.L.R.B. 612 (1971), enforcement denied, 460 F.2d 1 (2d Cir.), cert. denied, 409 U.S. 1041 (1972); General Drivers Local 563, 186 N.L.R.B. 219 (1970); Television \& Radio Artists Washington-Baltimore Local, 185 N.L.R.B. 593 (1970), enforced, 462 F.2d 887 (D.C. Cir. 1972); Los Angeles Newspaper Guild Local 69, 185 N.L.R.B. 303 (1970), enforced, 443 F.2d 1173 (9th Cir. 1971); Teamsters Local 639, 158 N.L.R.B. 1281 (1966); Miami Newspaper Printing Pressmen Local 46, 138 N.L.R.B. 1346 (1962), enforced, 322 F.2d 405 (D.C. Cir. 1963).

'7 Farmer v. Carpenters Local 25, 97 S. Ct. 1056 (1977); International Ass'n of Machinists v. Wisconsin Empl. Rel. Comm'n, 427 U.S. 132 (1976); Association of Street Employees v. Lockridge, 403 U.S. 274 (1971); San Diego Bldg. Trades Council v. Garmon, 359 U.S. 236 (1959). Applying Garmon, the Supreme Court has held preempted a state cause of action premised on the theory that the establishment of a picket line constitutes inducement of breach of contract enjoinable under state tort law. Ex parte George, 371 U.S. 72 (1962); Dixie Mach. Welding \& Metal Works, Inc. v. Marine Eng'rs Beneficial Ass'n, 243 F. Supp. 489 (E.D. La. 1965); Curtis Bay Towing Co. v. National Maritime Union, 206 F. Supp. 741 (E.D. Pa. 1962). See also Consolidation Coal Co. v. UMW, 537 F.2d 1226 (4th Cir. 1976).

's Avco Corp. v. Aero Lodge 735, Int'l Ass'n of Machinists, 390 U.S. 557 (1968), permitted state court actions for enforcement of collective bargaining agreements to be removed to federal court pursuant to 28 U.S.C. $\S 1441$ (b) (1970), even though injunctive relief, available in the state court, could not be obtained in federal court because of the Norris-LaGuardia Act and the Sinclair decision. 
obligations without regard to an arbitrator's award, ${ }^{99}$ the Buffalo Forge majority's restriction of the availability of Boys Markets relief creates, to a degree, the same incentives for forum shopping that emerged under Sinclair. ${ }^{100}$

The Supreme Court failed to recognize the substantial policies supporting specific performance of no-strike obligations. Nor did the Court articulate persuasive reasons for denying such relief. In fact, had the Court given adequate consideration to the flexibility of equitable intervention, the fears of both the majority and the dissent about the consequences of injunctive relief pending arbitration would have been seen as unfounded.

\section{B. The Nature of a General Injunction Remedy for No-Strike Clause Breaches}

Justice White, writing for the Buffalo Forge majority; read Boys Markets as authorizing injunctive relief only where it would further the policy developed under section 301 favoring arbitration of labor disputes. But his narrow inquiry into whether the work stoppage was caused by an otherwise arbitrable dispute was only partially responsive to this central concern of the Boys Markets accommodation. Justice White assumed that prearbitration injunctive relief would encourage arbitration only if the strike had been precipitated by an arbitral dispute. Nothing is more fundamental to a collective bargaining agreement, however, than the scope of the union's nostrike obligation. Denying prearbitration injunctive relief when the work stoppage itself is of questionable validity under the bargaining agreement undermines the employer's incentive to agree to submit disputes to arbitration in exchange for the union's promise not to strike. ${ }^{101}$

" See Aaron, Labor Injunctions in the State Courts-Part One: A Survey, 50 VA. L. REv. 951 (1964).

100 See Buffalo Forge Co. v. United Steelworkers of America, 428 U.S. 397, 413 (1976) (Stevens, J., dissenting).

101 While unions expend great energy seeking to subject breach-of-contract claims to the arbitration process, management is frequently loath to submit disputes over sympathy strikes and picket line respect to arbitration. In fact, arbitration of such disputes may be regarded by many employers as too high a price to pay for the issuance of a post-arbitration order enjoining a strike. See generally Stewart, supra note 7, at 691-96; Schubert, Arbitration and Damage Claims for Violation of the No-Strike Clause, 16 LAB. L.J. 751 (1965). Whether employer apprehensions about arbitration of no-strike clause issues are justified is uncertain. One early arbitral decision laid down the following tests for ascertaining when refusals to cross a picket line would be deemed privileged even in the face of a no-strike obligation: (1) the picket line was established in furtherance of a "good faith labor dispute"; (2) the picket line was not in furtherance of a dispute with another employer with whom the picketed employer 
The concern expressed by both opinions in Buffalo Forge that prearbitration injunctive relief would inject a trial court into the merits of a breach-of-contract claim, rendering arbitration superfluous is valid but not insurmountable. However, Justice Stevens's suggestion that Boys Markets injunctions should issue only upon a "clear" violation of the no-strike clause is fraught with difficulty. As Justice White correctly pointed out, ${ }^{102}$ the "clear" violation standard would not reduce the degree of court intrusion into the merits. Given the ambiguity of collective bargaining agreements, it is likely that courts would intrude into the merits as much in determining whether there was a "clear" violation as they would in connection with an unrestricted injunction remedy. Moreover, when a district court judge determines that a strike "clearly" violates a contractual duty, the arbitrator would very likely feel bound by this determination. Thus the "clear" violation standard for Boys Markets relief threatens the independence of arbitrators. Furthermore, insofar as Justice Stevens also advocated a standard requiring that no-strike clause breaches be "clearly arbitrable" before Boys Markets relief

has no interest; (3) the picket line was not in furtherance of a jurisdictional dispute among unions; (4) the picket line was not a "demonstration" picket line having no purpose in furthering union interests in a labor dispute with the picketed employer; and (5) observance of the picket line was not for the purpose of pressuring the picketed employer to grant concessions to employees refusing to cross the line, or otherwise furthering the interests of employees respecting the picket line. Waterfront Employers Ass'n, 8 Lab. Arb. 273 (1947) (Kerr. Arb.); but see Waterfront Employers Ass'n, 9 Lab. Arb. 5 (1947) (Miller, Arb.) (same tests applied to reach opposite result). Some decisions do evince an unwillingness to declare respecting a picket line a violation of a no-strike obligation. See, e.g., Arkansas Louisiana Gas Co., 42 Lab. Arb. 626 (1964) (Quinlan, Arb.); Vermont Structural Steel Corp., 60 Lab. Arb. 842 (1973) (Hogan, Arb.); cf. Associated Gen. Contractors, 63 Lab. Arb. 32 (1974) (Gallagher, Arb.) (refusals by individual employees to cross were privileged by picket line clauses expressly permitting respect in the circumstances presented); Sears Roebuck \& Co., 35 Lab. Arb. 757 (1960) (Miller, Arb.) (refusals to cross constitute a strike but are protected by an express clause privileging respecting picket lines). Other arbitrators have not hesitated to find that refusals to cross the picket lines of other unions violate express no-strike clauses. See, e.g., Bowman Transp., Inc., 73-2 Lab. Arb. Awards (CCH) If 8429 (1972) (Johnston, Arb.); Amalgamated Lace Operative, 54 Lab. Arb. 140 (1969) (Frey, Arb.); Michigan Consol. Gas, 70-1 Lab. Arb. Awards (CCH) I 8294 (1969) (McIntosh, Arb.); Gulf Coast Motor Lines, 67-2 Lab. Arb. Awards (CCH) ๆ8598 (1967) (Williams, Arb.); General Am. Transp. Corp., 41 Lab. Arb. 214 (1963) (Abrahams, Arb.); Mach's New York, 40 Lab. Arb. 954 (1962) (Scheiber, Arb.); New England Master Textile Engravers Guild, 9 Lab. Arb. 199 (1947) (Wallen, Arb.); cf. Shop Rite Foods, Inc., 58 Lab. Arb. 965 (1972) (Ray, Arb.) (union instruction to respect picket line violates no-strike clause, but individual refusals are privileged); Metro East Journal, 47 Lab. Arb. 610 (1966) (Kelliher, Arb.) (union not responsible for breach caused by individual decisions to respect, hence no violation); Pilot Freight Carriers, Inc. 22 Lab. Arb. 761 (1954) (Maggs, Arb.) (refusals to cross violate clause permitting respect only for strikes authorized by local or international union except where refusal is based on reasonable fear of violence).

102428 U.S. at 412. 
is appropriate, ${ }^{103}$ his opinion is in conflict with Gateway Coal, which applied the presumption of arbitrability established by the Steelworkers Trilogy ${ }^{104}$ to Boys Markets litigation. ${ }^{105}$

Both opinions overlooked the fact that trial courts possess sufficient authority to avoid both a determination of the merits of nostrike obligations and the abuses of power associated with the labor injunctions of the past. ${ }^{108}$ The injunction need be nothing more than an order preserving the status quo pending an arbitral determination of the merits of a claimed breach of an express or implied nostrike obligation. Preserving the status quo is one of the traditional functions of equity, ${ }^{107}$ and an order requiring expedited arbitration

${ }^{103}$ See note 79 supra.

${ }_{104}$ United Steelworkers of America v. American Mfg. Co., 363 U.S. 564 (1960); United Steelworkers of America v. Warrior \& Gulf Nav. Co., 363 U.S. 574 (1960); United Steelworkers of America v. Enterprise Wheel \& Car. Corp., 363 U.S. 593 (1960).

1as 414 U.S. at 379. See Note, Labor Injunctions, Boys Markets, and the Presumption of Arbitrability, 85 HARv. L. REv. 636 (1972) (proposing that no presumption in favor of arbitrability be indulged in Boys Markets litigation).

${ }^{106}$ FED. R. CIv. P. 65, which did not exist when the Norris-LaGuardia Act was passed, contains many of the same procedural protections that are found in the Norris-LaGuardia Act. Sections $7 \& 9$ of the Norris-LaGuardia Act and Rule 65 both require that injunctions be issued only after notice to the adverse party and that injunction orders prohibit only the specific acts complained of. Compare 29 U.S.C. $\$ \S 107,109$ (1970) with FED. R. Crv. P. 65(a)(1), (d). Both permit the issuance of temporary restraining orders without notice upon a showing of irreparable injury and require the posting of a bond as a condition of issuance. Compare 29 U.S.C. $\$ 107$ (1970) with FED. R. Civ. P. 65(b), (d).

The lower federal courts have, consistent with Boys Markets, accommodated the protections of the Norris-LaGuardia Act with Rule 65 and the policies of $\S 301$ in establishing a uniform set of procedures for labor injunctions. The appellate courts have agreed that $\S 7$ of the Norris-LaGuardia Act remains applicable to the extent it is consistent with the policies of $\S 301$. Thus, the requirement of a hearing, including the receipt of live testimony, in open court prior to the issuance of an injunction applies to Boys Markets injunctions unless such a hearing would be useless. See Transit Union Div. 1384 v. Greyhound Lines, Inc., 529 F.2d 1073 (9th Cir.), vacated and remanded on other grounds, 97 S. Ct. 43 (1976); Celotex Corp. v. Oil.Workers, 516 F.2d 242 (3d Cir. 1975); Hoh v. Pepsico, Inc., 491 F.2d 556 (2d Cir. 1974). The shorter time period for the effectiveness of temporary restraining orders prescribed by the Norris-LaGuardia Act has also been adopted, Celotex Corp. v. Oil Workers, 516 F.2d 242 (3d Cir. 1975), but the "public officers" finding requirement of the Norris-LaGuardia Act has been deemed to be "probably" inappropriate in Boys Markets cases. United States Steel Corp. v. UMW, 456 F.2d 483 (3d Cir.), cert. denied, 408 U.S. 923 (1972).

The Seventh Circuit, however, in a dictum written by then-Judge Stevens, indicated that Boys Markets itself suggests that all of the procedural requisites of $\S 7$ are inapplicable. Associated Gen. Contractors v. Illinois Conf. of Teamsters, 486 F.2d 972, 975-76 n.8 (7th Cir. 1973). A district judge has held $\S 8$ inapplicable to Boys Markets cases, Latrobe Steel Co. v. United Steelworkers, 405 F. Supp. 787 (W.D. Pa. 1975), vacated and remanded on other grounds, 545 F.2d 1336 (3d Cir. 1976), an issue raised before the trial judge in Buffalo Forge but not resolved because of his denial of the injunction on other grounds. See 517 F.2d at 1209 n.3.

${ }^{107}$ See Tanner Motor Livery, Ltd. v. Avis, Inc., 316 F.2d 804, 808 (9th Cir. 1963); Developments in the Law-Injunctions, 78 HARv. L. REv. 994, 1058 (1965). 
should be a sufficient safeguard against the status quo order becoming, in effect, a final determination of the right to strike or respect a picket line. The restraining order preserving the status quo can be made expressly dissolvable upon a showing of employer delay in adhering to the order for expedited arbitration. The injunction can require the arbitrator's award to issue immediately after an expedited hearing, with a written decision to follow later. The trial court can also direct the arbitrator to decide whether further or additional coercive relief against the work stoppage is warranted, with any such award enforceable in confirmation proceedings. ${ }^{108}$ The concern of the Norris-LaGuardia Act that status quo orders remain in effect for only a limited period of time can be served by tailoring the injunction to expire at the conclusion of an appropriate period, with extensions granted only for good cause, such as dilatory tactics on the union's part, or exceptional circumstances excusing the parties from completing their case presentations in the period established by the order.

The real issue then turns on the propriety of an order enjoining a strike alleged to be in breach of an express or implied no-strike obligation and restoring the status quo pending arbitration, requiring in effect that the union establish its contractual right to strike in arbitration prior to exercising that right. By restricting Boys Markets relief to situations where a breach-of-contract strike arises over an arbitrable dispute, the majority in Buffalo Forge avoided this issue. Justice Stevens alluded to the propriety of a status quo order when he referred to the traditional labor-management relations maxim that the party seeking arbitration must accept the condition of which he complains pending the arbitrator's decision. ${ }^{109}$ The maxim, he noted, is grounded in the need for production to continue, ${ }^{100}$ and usually benefits the employer because unions and employees are frequently the complaining parties. The policy supporting the maxim, if not the maxim itself, undermined the union's contention that it should be permitted to disrupt production pending the arbitrator's decision on the no-strike clause issue.

Furthermore, in Gateway Coal the Supreme Court affirmed the trial court's order requiring the employer to reestablish the status quo-suspension of the foremen whose presence constituted an alleged safety hazard-as a condition of granting injunctive relief. If

${ }^{105}$ See, e.g., New Orleans S.S. Ass'n v. General Longshore Workers Local 1418, 389 F.2d 369 (5th Cir.), cert. denied, 393 U.S. 828 (1968). See also Gould, supra note 4, at 244-50.

108 428 U.S. at 425.

110 Id. at 427 n.21; see also Ford Motor Co., 3 Lab. Arb. 779 (1944) (Shulman, Arb.). 
equity is authorized to require the status quo of employers, it should be empowered to impose similar restraints on unions. ${ }^{111}$

In essence, the limited form of relief suggested here would provide arbitrators with an atmosphere free from economic pressure in which to resolve knotty issues concerning whether the grievancearbitration provisions of particular contracts can be read to imply no-strike obligations, and whether the parties' contractual prohibition of strikes extends to sympathy strikes or picket line respect. Consistent with the conventional presumption in favor of arbitrability of labor disputes, injunctive relief would be inappropriate only if it could be established that the parties either expressly excluded sympathy work stoppages from the no-strike clause or unambigously excluded no-strike issues from their grievance-arbitration procedures.

Finally, the Buffalo Forge majority's fear that allowing injunctions of strikes in breach of contract pending arbitration would inundate the federal courts with preliminary injunction litigation seems particularly questionable. ${ }^{112}$ The argument against injunctive relief in this context is often put the other way around: enjoining breach-of-contract strikes does not contribute to the goal of industrial peace because these strikes account for such a small proportion of the man-days idled each year by labor disputes. ${ }^{113}$ Enjoining

11 In Detroit Newspaper Publishers Ass'n v. Detroit Typographical Union No. 18, 471 F.2d 872 (6th Cir. 1972), cert. denied, 411 U.S. 967 (1973), the court vacated on other grounds the trial court's issuance of an injunction enforcing a status quo provision in the collective bargaining agreement against the employer, but indicated its decision was without prejudice to any future proceedings to enforce the status quo pending an arbitrator's determination of the applicability of the clause. See Gould, supra note 4, at 239-44, concluding that in exceptional circumstances courts issuing Boys Markets injunctions possess the power to reinstate the status quo pending arbitration. But see Transit Union Div. 1384 v. Greyhound Lines, Inc., 529 F.2d 1073 (9th Cir. 1976), vacated and remanded, 97 S. Ct. 43 (1976). In its original opinion the Ninth Circuit upheld the issuance of a preliminary injunction requiring the company to maintain the status quo by not implementing changes in work schedules pending arbitration of a union grievance challenging these changes. After the Supreme Court vacated and remanded for reconsideration in light of Buffalo Forge, however, the court reversed the trial judge's injunction, emphasizing the absence of a specific contractual provision requiring maintenance of the status quo by the employer pending arbitration and concluding that the implication of an employer obligation to preserve the status quo would be improper where the employer's action did not threaten to frustrate or interfere with the arbitration process. Transit Union Div, 1384 v. Greyhound Lines, Inc., 550 F.2d 1237 (9th Cir. 1977).

112 Alleviating the burdens on the federal judiciary by limiting access to the federal courts finds expression in other decisions issued during the 1975 Term. See Stone v. Powell, 423 U.S. 817 (1976); Francis v. Henderson, 425 U.S. 536 (1976) (restricting the availability of federal habeas corpus relief).

${ }^{113} \mathrm{H}$. Wellington, supra note 33, at 117-19 (citing Bureau of Labor Statistics data on work stoppages for 1961 and 1965). See also Vladeck, supra note 10, at 93; Dunau, supra note 10 , at 465 . 
such conduct may even be counterproductive, it is argued, because when a strike in breach of contract does occur, feelings run so high that an injunction will not change matters. ${ }^{14}$ More refined data on work stoppages than those relied on by the Court indicate that half of all breach-of-contract strikes occur in two industries-mining and construction-and that breach-of-contract strikes represent onethird of all work stoppages in the country. ${ }^{115}$ Nevertheless, because almost all collective bargaining agreements include grievance procedures culminating in arbitration, most breach-of-contract strikes would probably be enjoinable under existing Boys Markets standards. ${ }^{116}$ Thus the data do not suggest that expanding the Boys Markets remedy to include specific performance relief pending arbitration would inundate the federal courts with massive preliminary injunction litigation.

\section{Injunctive Relief and "Employee-Oriented" Grievance- Arbitration Procedures}

One of the most serious shortcomings of the majority opinion in Buffalo Forge was the failure to analyze fully the grievancearbitration procedure provided in the parties' bargain. That failure resulted in the unsupported assertion that the employer could compel arbitration of its breach-of-contract claim even though the grievance procedures preliminary to arbitration were "employeeoriented"117 and excluded employer claims of contract breach. If Boys Markets injunctions may be granted to employers in cases in which grievance-arbitration procedures are "employee-oriented," Buffalo Forge may have sub silentio, and apparently unintentionally, overruled Atkinson $v$. Sinclair Refining Co. ${ }^{118}$ In that case the Supreme Court held that an employer's section 301 damage action would not be stayed pending arbitration where an "employeeoriented" grievance procedure denied the employer the right to initiate the grievance-arbitration mechanism.

Employers have sought to incorporate "employee-oriented"

'1' H. Wellington, supra note 33, at 117-19.

115 Analysis of Work Stoppages, 1971, Dep't of Labor Bull. No. 1777, at 5, 23-24 (1973); Analysis of Work Stoppages, 1973, Dep't of Labor Bull. No. 1877, at 16 (1975).

III About $96 \%$ of collective bargaining agreements contain procedures providing for arbitration of contract disputes, although many arbitration provisions exclude certain types of disputes from arbitral resolution. See 2 BNA, Collective Bargaining Negotiations and Contracts, Basic Pattrens in Union Contracts, 51:6 (1975).

i7 See text and notes at notes $52-53$ supra.

118 370 U.S. 238 (1962); see note 54 supra. 
grievance procedures in bargaining agreements ${ }^{119}$ not only to prevent stays of damage actions pending arbitration, but to negate any implication that employees or a union can erode management's right to issue work orders. When the employer has been denied access to the grievance procedure he is not required to secure a determination by an arbitrator that a disputed work order was proper under the bargaining agreement before insisting on obedience to the order. This principle, too, appears threatened by the majority's analysis of the applicable bargaining agreement in Buffalo Forge.

If the parties have clearly excluded employer claims of breach of contract from the grievance-arbitration procedure, enjoining the work stoppage at the request of the employer and requiring arbitration of the strike issue contravenes the parties' bargain. Even though the employer who resisted arbitration of strike claims at the bargaining table is now seeking the order compelling arbitration, and the union, which probably demanded arbitration of strike claims initially, now resists, to permit the employer to invoke the arbitral process offends notions of freedom of contract. ${ }^{120}$

On the other hand, when the employer, as well as the employees and the union, may invoke the grievance procedure, specific performance of no-strike obligations coupled with an order to arbitrate the strike issue does not run afoul of the collective bargaining agreement ${ }^{121}$ and is consistent with Atkinson v. Sinclair on the damage action side of section 301 . In view of the significant policy considerations favoring injunctions enforcing no-strike obligations, such a limited remedy constitutes a more appropriate accommodation of the Norris-LaGuardia Act and section 301 than the resolutions offered by either the majority or minority opinion in Buffalo Forge. ${ }^{122}$

119 According to one survey, in 1975 approximately $26 \%$ of the collective bargaining agreements in manufacturing industries and $23 \%$ in nonmanufacturing industries contained grievance-arbitration provisions permitting employers to file grievances. $2 \mathrm{BNA}$, CoLlective Bargaining Negotiations and Contracts, Basic Patterns in Union Contracts 51 (1975). The comparable percentages in 1971 were $16 \%$ for manufacturing industries and $14 \%$ for nonmanufacturing industries. 2 BNA, Collective Bargaining Negotiations and Contracts, Basic Patterns in Union Contracts 51 (1971).

${ }^{120}$ H. Wellington, supra note 33, at 112-17 (1968); see also United States Steel Corp. v. UMW, 519 F.2d 1236 (5th Cir. 1975) (trial court's issuance of a Boys Markets injunction was improper in part because only a union or individual grievance against an employer, and not an employer grievance against a union, was an appropriate predicate for Boys Markets relief).

${ }^{121}$ See, e.g., Johnson Builders, Inc. v. United Bhd. of Carpenters Local 1095, 422 F.2d 137 (10th Cir. 1970) (affirming a stay of an employer $\S 301$ action where the employer had access to the contractual grievance procedure).

122 Unions would not be required to assume the risk of calling a potentially illegal strike to force the employer to commence the arbitral proceeding. Upon the establishment of a foreign picket line, for example, the union, instead of authorizing picket line respect, could demand that the employer initiate the grievance-arbitration mechanism to determine 
Under the proposed remedy, a court would do no more than act in aid of the grievance-arbitration mechanism by requiring that production continue pending the arbitrator's award. ${ }^{123}$

Application of the suggested remedy is concededly more difficult in cases like Buffalo Forge where both the company and the union possess a right to appeal to arbitration, but only employees can initiate the grievance procedure. Because both parties have access to the arbitration mechanism, one could argue that an order requiring arbitration of the no-strike issue is less offensive to freedom-of-contract ideals than a similar order where the employer is denied a right to appeal to arbitration. By permitting the employer to appeal to arbitration, the parties may have intended to allow employer claims to be submitted at advanced stages of the grievance procedure, or to be submitted directly to arbitration. The ambiguity over whether the employer is in fact excluded from arbitration is best resolved by an order enjoining the alleged breach-ofcontract strike and compelling arbitration, with the proviso that the injunction will automatically dissolve upon the arbitrator's ruling that the employer had no right to present breach-of-contract claims to arbitration.

\section{Enjoining Activity Arguably Protected by the NLRA}

The refusal of both the majority and the dissent in Buffalo Forge to sanction a prearbitration injunction remedy in the context of sympathy strikes or refusals to cross picket lines may stem from an unarticulated reluctance to threaten time-honored traditions of the union movement or to interfere with activity that may be "protected" by the National Labor Relations Act.

whether picket line respect is covered by the scope of the no-strike obligation. An employer's unwillingness to invoke arbitration when the union has refrained from striking should defeat any subsequent request by the employer for an injunction restraining the picket line respect. This conclusion comports with $\S 8$ of the Norris-LaGuardia Act, insofar as that provision is applicable to Boys Markets relief. See note 106 supra. Normally, an employer's request for Boys Markets relief and an order compelling arbitration should satisfy $\S$ 8's requirement of a reasonable effort to settle the dispute by arbitration. Evidence of unwillingness to proceed to arbitration, however, could demonstrate noncompliance and be grounds for denying relief. See Chief Freight Lines Co. v. Local 886, Int'l Bhd. of Teamsters, 514 F.2d 572, 580-82 (10th Cir. 1975); Valmac Indus., Inc. v. Food Handlers Local 425, 519 F.2d 263 (8th Cir. 1975), vacated and remanded, 428 U.S. 906 (1976), ruling that an employer would not be permitted to abandon its demand for arbitration after issuance of a Boys Markets injunction.

123 The conventional precondition to the right to maintain court action-that a party exhaust contract remedies or demonstrate that it has been prevented from doing so by factors outside its control, Republic Steel Co. v. Maddox, 379 U.S. 650 (1965)-is satisfied because the work stoppage itself prevents the employer from exhausting the contract remedy while production continues. 
After vacillating, ${ }^{124}$ the National Labor Relations Board has incorporated into the NLRA the notion that "[f]rom the point of view of union morality, a good union man never crosses a picket line, no matter whose picket line." 125 The Board has ruled that, unless a governing collective bargaining agreement provides to the contrary, respecting the picket line of another union at another employer's premises is "protected" activity. ${ }^{126}$ The discharge of an employee for refusing to cross a picket line interferes with the employee's right under sections 7 and 8(a)(1) of the NLRA to engage in concerted activities for "mutual aid or protection and to assist labor organizations," ${ }^{122}$ and it violates section 8(a)(3) by discriminating against employees "in regard to hire or tenure of employment" to discourage union membership. ${ }^{128}$

124 Compare Cyril de Cordova \& Bro., 91 N.L.R.B. 1121 (1950) (refusal to cross is "protected"), with Auto Parts Co., 107 N.L.R.B. 242 (1953) (refusal to cross constitutes insubordination justifying discharge); compare Redwing Carriers, Inc., 130 N.L.R.B. 1208 (1961) (refusal to cross constitutes "unprotected" activity justifying discharge, and $\S 502$ is not applicable because employees were not faced with "abnormally dangerous working conditions"), with Redwing Carriers, Inc., 137 N.L.R.B. 1545 (1962), enforced sub nom. Teamsters Local 79 v. NLRB, 325 F.2d 1011 (D.C. Cir. 1963), cert. denied 377 U.S. 905 (1964) (resurrecting Cordova and concluding that activity is "protected" but permitting "replacement" of the employee refusing to cross the picket line if "business justification" for "replacement" proven). For a discussion of the early Board cases, see Kennedy, The "Right" to Refuse to Cross a Picket Line: Limitations Imposed by Courts and Legislation, 2 ST. Louis L.J. 66 (1952); O'Connor, Respecting Picket Lines: A Union View, 7 N.Y.U. Conf. on LAB. 235 (1951); Petro, National Labor Policy and Respect for Picket Lines, 3 LAB. L.J. 83 (1952); Thatcher \& Finley, Respect for Picket Lines, 32 Neb. L. REv. 25 (1952).

125 J. Barbash, Labor Unions in Action 129 (1948). But see Raskin, Is the Picket Line Obsolete? Saturday Review/WorLd. Oct. 19, 1974, at 12-17.

${ }_{126}$ Redwing Carriers, Inc. 137 N.L.R.B. 1545 (1962), enforced sub nom. Teamsters Local 79 v. NLRB, 325 F.2d 1011 (D.C. Cir. 1963), cert. denied, 377 U.S. 905 (1964).

${ }^{127}$ Section 7 provides in pertinent part:

Employees shall have the right to self-organization, to form, join, or assist labor organizations, to bargain collectively through representatives of their own choosing, and to engage in other concerted activities for the purpose of collective bargaining or other mutual aid or protection, and shall also have the right to refrain from any or all of such activities....

29 U.S.C. $\S 157$ (1970). Section $8(\mathrm{a})$ (1) provides, “(a) It shall be an unfair labor practice for an employer - (1) to interfere with, restrain, or coerce employees in the exercise of the rights guaranteed in section 157 of this title . . ." 29 U.S.C. $§ 158$ (a)(1) (1970).

${ }^{12 x}$ Section 8(a)(3) provides, "(a) It shall be an unfair labor practice for an employer. . . (3) by discrimination in regard to hire or tenure of employment or any term or condition of employment to encourage or discourage membership in any labor organization . . . ."29 U.S.C. § 158(a)(3) (1970). See section 8(b)(4), 29 U.S.C. $\S 158(b)(4)(1970)$, which reads in part:

Provided, That nothing contained in this subsection [section $8(\mathrm{~b})(4)$ ] shall be construed to make unlawful a refusal by any person to enter upon the premises of any employer (other than his own employer), if the employees of such employer are engaged in a strike ratified or approved by a representative of such employees whom such employer is required to recognize under this subchapter . . . . 
The "protected" right delineated by the NLRB is not absolute. Under the doctrine of Redwing Carriers, Inc. ${ }^{120}$ employees engaging in sympathy strikes by respecting picket lines assume the status of economic strikers, and if business efficiency demands it, an employer may "replace"-not "discharge"- such an employee. ${ }^{130}$ Furthermore, the Board's willingness to recognize a protected right to refuse to cross a foreign picket line has met resistance in the appellate courts, especially in cases where collective bargaining agreements contain no-strike obligations expressly or impliedly waiving the right to respect picket lines. ${ }^{131}$ Although purporting not to promulgate any "sweeping abstract principles," the Supreme Court in NLRB v. Rockaway News Supply Co. ${ }^{132}$ refused to accept the Board's complete disregard of the governing collective bargaining agreement's no-strike provisions in finding an employee's refusal to cross a picket line at the premises of another employer "protected."

12137 N.L.R.B. 1545 (1962), enforced sub nom. Teamsters Local 79 v. NLRB, 325 F.2d 1011 (D.C. Cir. 1963), cert. denied, 377 U.S. 905 (1964).

130 Under established NLRB doctrine employees engaging in an economic strike may be permanently replaced but not discharged by their employer. NLRB v. Mackay Radio \& Tel. Co., 304 U.S. 333 (1938). The distinction in the context of respecting picket lines is nearly incomprehensible. Reviewing one version of this dichotomy, the Supreme Court commented: "The Court of Appeals said, 'We cannot follow the Board's reasoning.' Nor can we." NLRB v. Rockaway News Supply Co., 345 U.S. 71, 75 (1953).

In assessing "business justification" the Board inquires whether the "replacement" occurred "immediately" or within "a short period after" the replaced employee's services were terminated, whether the loss of production will likely result in a loss of a substantial customer, whether other employees or supervisors who would cross the picket line are available to perform the work, and whether the respecting employees can perform other work not involving crossing the picket line. See Newberry Energy Corp., 227 N.L.R.B. No. 58 (1976); Overnite Transp. Co., 209 N.L.R.B. 691 (1974); Overnite Transp. Co., 212 N.L.R.B. 515 (1974); Braswell Motor Freight Line, 189 N.L.R.B. 503 (1971). See generally Haggard, Picket Line Observance as Protected Concerted Activity, 53 N.C.L. REv. 43 (1974). Cases prior to 1970 are collected and discussed in Carney \& Florsheim, The Treatment of Refusals to Cross Picket Lines: "By-Paths and Indirect Crookt Ways," 55 CoRneul L. Rev. 940 (1970).

i3! See Montana-Dakota Utilities Co. v. NLRB, 455 F.2d 1088 (8th Cir. 1972); NLRB v. L.G. Everist, Inc., 334 F.2d 312 (8th Cir. 1964); NLRB v. Ilinois Bell Tel. Co., 189 F.2d 124 (7th Cir.), cert. denied, 342 U.S. 885 (1951). For cases agreeing with the Board's interpretation that the no-strike obligations in the applicable agreement did not prohibit picket line respect, see Kellogg Co. v. NLRB, 457 F.2d 519 (6th Cir.), cert. denied, 409 U.S. 850 (1972); General Tire \& Rubber Co. v. NLRB, 451 F.2d 257 (1st Cir. 1971); Virginia Stage Lines, Inc. v. NLRB, 441 F.2d 499 (4th Cir.), cert. denied, 404 U.S. 856 (1971). One court has decided that "[o]ne who refuses to cross a picket line by reason of physical fear does not act on principle. He makes no common cause, and contributes nothing to mutual aid or protection in the collective bargaining process." Thus the activity was not protected. NLRB v. Union Carbide Corp., 440 F.2d 54 (4th Cir.), cert. denied, 404 U.S. 826 (1971). See also G \& P Trucking Co. v. NLRB, 539 F.2d 705 (4th Cir. 1976). See generally Connolly, Section 7 and Sympathy Strikes: The Respective Rights of Employers and Employees, 25 LAB. L.J. 760 (1974).

132345 U.S. 71, 75 (1953), affirming on other grounds 197 F.2d 111 (2nd Cir. 1952), denying enforcement of 95 N.L.R.B. 336 (1951). 
The Board had apparently conceded that the provisions of the bargaining agreement would establish a complete defense to the unfair labor practice charge, ${ }^{133}$ but it had ruled that the entire contract was null and void for the purposes of its proceeding because the contract contained an illegal union security provision. The Supreme Court held that the no-strike clause was severable from the faulty security provision, and found on an independent review of the record that the no-strike clause was intended to cover employee refusals to cross picket lines. ${ }^{134}$ The employee's discharge was therefore not an unfair labor practice.

While conceding that the "protected" right to refuse to cross a picket line may be properly waived, ${ }^{135}$ the Board has been reluctant to find a waiver in the mere presence of a collectively-bargained nostrike clause without additional evidence that the parties intended the no-strike obligation to cover sympathy strikes or refusals to cross picket lines. ${ }^{136}$ The Board's position is illustrated by the recent case of Gary-Hobart Water Co. ${ }^{137}$ When the case first came before the Board, it applied the Collyer ${ }^{138}$ doctrine, ruling that the question whether the right to engage in picket line respect was waived by a no-strike clause was so intertwined with the interpretation of the parties' contract that the policies of the NLRA would be best effectuated by deferring to the contractual grievance-arbitration machinery for a decision. ${ }^{139}$ When the employer refused to arbitrate, how-

133 See 345 U.S. at 76.

134 The Court cited in support of its ruling NLRB v. Sands Mfg. Co., 306 U.S. 332 (1939), which held that it was not an unfair labor practice to discharge employees who struck in breach of contract. 345 U.S. at 80 .

135 Keller-Crescent Co., 217 N.L.R.B. 685, 687 (1975), enforcement denied on other grounds, 538 F.2d 1291 (7th Cir. 1976). But see NLRB v. Magnavox Co., 415 U.S. 322 (1974) (ruling that employee $\$ 7$ rights to distribute literature in nonwork areas during nonwork time on the issue of union representation or nonrepresentation could not be "waived" by bargaining agreement provisions).

${ }_{136}$ See, e.g., Kellogg Co., 189 N.L.R.B. 748 (1971), enforced, 457 F.2d 519 (6th Cir.), cert. denied, 409 U.S. 850 (1972). But see Alliance Mfg. Co., 200 N.L.R.B. 697 (1972) (adopting administrative law judge's ruling that refusals to cross a picket line at the employees' place of employment were unprotected because prohibited by a collectively bargained no-strike clause). See also Carney \& Florsheim, supra note 130, at 959-61.

137200 N.L.R.B. 647 (1972), decided on the merits, 210 N.L.R.B. 742 (1974), enforced, 511 F.2d 284 (7th Cir. 1975).

${ }^{138}$ Collyer Insulated Wire, 192 N.L.R.B. 837 (1971), ruled that where a dispute between the parties raises both contractual and unfair labor practice issues, but essentially concerns the meaning of the contract, the Board should defer unfair labor practice proceedings pending submission to, and resolution of the dispute by, an arbitrator, provided the arbitration can provide an appropriate and full remedy for the alleged contract violation. But see note 155 infra.

${ }^{139}$ Gary-Hobart Water Corp., 200 N.L.R.B. 647 (1972). See also Diamond Nat'l Corp., 197 N.L.R.B. 560 (1972). 
ever, the Board took the case again ${ }^{140}$ and was forced to resolve the question on the merits.

The production and maintenance employees had struck at the expiration of their bargaining agreement and had established a picket line in support of their demands. The clerical employees, governed by an unexpired collective bargaining agreement that prohibited "strikes, slowdowns, or other interruptions of work," refused to cross the production and maintenance employees' picket line. Observing that the right to honor a picket line is "protected" but may be waived by appropriate provisions in a bargaining agreement, the Board concluded that the broad no-strike provision did not waive the employees' right to respect the picket line.

The Board majority's analysis of the scope of the no-strike obligation rested on two arguments. First, the majority reasoned that the no-strike obligation is only as broad as the scope of an agreement's grievance-arbitration provisions, citing Gateway Coal, which, as the dissent properly noted, ${ }^{141}$ involved a collective bargaining agreement without an express no-strike provision. Foreshadowing the Supreme Court majority's position in Buffalo Forge, ${ }^{142}$ the Board majority observed that picket line respect was not a work stoppage caused by a grievance the parties were contractually bound to arbitrate. It followed, according to the majority, that the picket line respect was not a dispute cognizable under the grievance-arbitration mechanism. Thus the picket line respect did not fall within the scope of the no-strike obligation, and there was no waiver of the protected right. ${ }^{143}$

The Board majority's second argument was that the parties' bargaining history showed that the employer had proposed a provision, rejected by the union in the negotiations, that would have specifically prohibited refusing to cross another union's picket line. ${ }^{144}$ From this, the Board concluded that the parties construed

160 Gary-Hobart Water Corp., 210 N.L.R.B. 742 (1974).

14 Id. at 749; see text at notes $27-28$ supra.

112 See text at notes 60-62 supra.

${ }^{14}$ This analysis of the scope of a no-strike clause as dependent on the scope of the agreement's grievance-arbitration provisions was also utilized in Hoffman Beverage Co., 163 N.L.R.B. 981 (1967), and served as an alternative holding in Machinists Lodge 284, 190 N.L.R.B. 208 (1971).

11 The court of appeals in Montana-Dakota Utils. Co. v. NLRB, 455 F.2d 1088 (8th Cir. 1972), used bargaining history in a similar fashion to uphold the employer's interpretation of a no-strike clause. The court found that union proposals to restrict the scope of the no-strike clause were rejected by the company, indicating that the parties construed the broad no. strike clause as prohibiting picket line respect. See also Hearst Corp., 161 N.L.R.B. 1405 (1966), enforced sub nom. News Union v. NLRB, 393 F.2d 673 (D.C. Cir. 1968). But see 
the existing no-strike provision to sanction picket line respect. ${ }^{145}$

The Court of Appeals for the Seventh Circuit enforced the Board's order and endorsed its reasoning. ${ }^{146}$ The court, following the Board majority, interpreted Gateway Coal to mean that absent expression of a contrary intention a no-strike obligation is only as broad in scope as an agreement's grievance-arbitration provision. ${ }^{147}$ Since the arbitration clause subjected only disputes about the terms and provisions of the contract to arbitration, and respecting another union's picket line was not a dispute "arising under or in connection with" the agreement, the picket line respect was "neither arbitrable nor subject to the no-strike provisions."148 The picket line respect was thus not prohibited by the bargaining agreement's no-strike clause and was "protected" activity. The court found it was not necessary to examine the bargaining history of the no-strike clause, but that history "only reinforced" its conclusion that the right to engage in a sympathy strike and to refuse to cross another union's picket line had not been waived or otherwise prohibited by the bargaining agreement. ${ }^{149}$

Unquestionably, the bargaining history can be persuasive evidence of the intended coverage of a no-strike clause. But the reasoning of the Board majority and the court of appeals, premised on the coterminous nature of the grievance-arbitration provisions and the no-strike clause, was seriously flawed. Both the Board and the court assumed that because picket line respect is not triggered by an otherwise arbitrable grievance, a work stoppage of this nature presents no question "arising under or in connection with" the agreement as required by the arbitration clause. But the appropriate question is not whether the sympathy strike or picket line respect was caused by an arbitrable grievance, but whether such a work stoppage is prohibited by the no-strike clause. Clearly, this is an issue arising "under or in connection with" the interpretation of part of the agreement-the no-strike clause. Therefore, it is a

Kellogg Co. v. NLRB, 457 F.2d 519 (6th Cir.), cert. denied, 409 U.S. 850 (1972) (rejecting the use of any extrinsic evidence of bargaining history as an aid in interpreting the no-strike clause at issue).

is 210 N.L.R.B. at 746. Applying the business justification doctrine of Redwing, the Board also determined that the employer had not met its burden of showing a business need for terminating the employees of the clerical unit for refusing to work, since two months after their discharge fewer than six had been replaced. Id. at 746-47.

14 Gary-Hobart Water Corp. v. NLRB, 511 F.2d 284 (7th Cir. 1975).

17 Id. at 286-87.

148 Id. at 288.

is Id. 
question subject to the conventional arbitration clause involved in the Gary-Hobart case.

To a large extent the flawed reasoning of Gary-Hobart is attributable to the assumption on which the analysis rests-that the scope of the grievance-arbitration provisions and the no-strike clause are presumed to be coterminous. This presumption made sense in the context of Gateway Coal, where the Court was concerned with a strike caused by an arbitrable dispute. Because the employer had promised to arbitrate the dispute that triggered the strike, the union was presumed to have promised not to strike over such a dispute as part of the quid pro quo. In the context of a sympathy strike or picket line respect, however, it is irrelevant whether the dispute that precipitates the work stoppage is arbitrable. The dispute that causes the sympathy strike or picket line respect does not arise between the sympathy strikers and their employer and is not covered by their collective bargaining agreement. Thus the employer could not have agreed to arbitrate the precipitating dispute, and there is no ground for either implying or not implying an agreement not to strike as a quid pro quo.

The majority in Buffalo Forge implicitly recognized that the scope of grievance-arbitration procedures and no-strike clauses should not be presumed to be be coterminous in the context of sympathy strikes and respect for picket lines. Although prearbitration injunctive relief against the sympathy strike was not ordered, the majority ruled that the dispute over the scope of the no-strike clause was arbitrable. ${ }^{150}$ Thus the Court left the arbitrator free to construe the no-strike clause as prohibiting sympathy strikes, even though the dispute that caused the sympathy work stoppage was not arbitrable. In addition, Justice Stevens observed that in many agreements the employer has agreed to mandatory arbitration only in exchange for a no-strike clause that prohibits strikes over disputes that are not arbitrable. ${ }^{151}$ This suggests that, unless the agreement specifically so provides, an otherwise unrestricted express nostrike clause should not be construed as coextensive with the scope of grievance-arbitration provisions when the disputed issue concerns the permissibility of a sympathy work stoppage.

130428 U.S. at 410 .

151428 U.S. at 419 n.9 (Stevens, J., dissenting), citing Feller, $A$ General Theory of the Collective Bargaining Agreement, 61 CAL. L. REv. 663, 757-60 (1973), which in turn relied on Bureau of Labor Statistics studies showing that only $22.9 \%$ of no-strike clauses were expressly limited to issues subject to arbitration. See Major Collective Bargaining Agreements: Grievance Procedures, Dep't of Lab. Bull. No. 1425-1, at 86 (1964). 
In construing the proper scope of a no-strike obligation, the Court of Appeals for the District of Columbia was probably on sounder footing than the Seventh Circuit in Gary-Hobart when it reasoned:

Petitioners point out that there is no explicit reference [in the agreement] to the crossing of picket lines and suggest initially that language which in terms inhibits only a strike is not to be read as restricting the observance of picket lines. But the practical relationship between work stoppages and the honoring of picket lines is so well understood in the industrial climate that we think that a clause of this kind using only the word 'strike' includes plant suspensions resulting from refusals to report for work across picket lines. ${ }^{152}$

The conventional wisdom is that courts are not deprived of section 301 jurisdiction to enforce a bargaining agreement when the conduct involved is arguably within the protections or the prohibitions of the NLRA. ${ }^{153}$ Unraveling the intricate and often subtle tapestry of Board law on the "protected" nature of sympathy strikes, however, requires precisely the type of judicial intervention that neither the policies of section 301 nor the Norris-LaGuardia Act permit in connection with equitable relief. Nevertheless, courts should not be reluctant to grant prearbitration injunctive relief when a sympathy strike or respect for the picket line of another union is the "arguably protected activity" in conflict with a bargaining agreement's no-strike obligation. As the Board itself recognized in the Gary-Hobart decision, ${ }^{154}$ the existence and scope of the "protected" right is so inextricably linked with the contractual obligations that arbitration is the preferred forum for untangling the statutory and contractual issues involved. An injunction order en-

152 News Union v. NLRB, 393 F.2d 673, 676-77 (D.C. Cir. 1968); see Montana-Dakota Utils. Co. v. NLRB, 455 F.2d 1088, 1093 (8th Cir. 1972). Distinguishing Gary-Hobart and Hyster Co. v. Employees Ass'n of Kewanee, 519 F.2d 89 (7th Cir. 1975), cert. denied, 428 U.S. 910 (1976), the panel in NLRB v. Keller-Crescent Co., 538 F.2d 1291 (7th Cir. 1976), determined that Buffalo Forge required that a different analysis be employed in unfair labor practice cases involving picket line respect than in $\S 301$ injunction proceedings. Adopting reasoning similar to that suggested in the text, the panel also held that the scope of the express no-strike clause should not be construed as coterminous with the grievancearbitration provisions in the collective bargaining agreement.

${ }^{133}$ Local 174, Teamsters v. Lucas Flour Co., 369 U.S. 95 (1962); see William E. Arnold Co. v. Carpenters Dist. Council, 417 U.S. 12 (1974); Meltzer, The Supreme Court, Congress, and State Jurisdiction over Labor Relations (pt. 2), 59 Colum. L. REv. 269, 289-92 (1959); Sovern, Section 301 and the Primary Jurisdiction of the NLRB, 76 HARv. L. Rev. 529, 559-61 (1963).

ist See text at note 139 supra. 
forcing the no-strike clause with the direction that an arbitrator decide the question of the employee's right to respect the picket line coincides with a determination that issues of this type may be appropriately resolved by arbitration. ${ }^{155}$ In addition, referring the merits of the controversy over the scope of the no-strike clause to arbitration more fully comports with the judiciary's role in enforcing bargaining agreements under section 301 by allowing specialists chosen by the parties to resolve specific disputes about the content of the parties' bargain.

In some circumstances, it should be noted, an employee's refusal to work in spite of a contractual no-strike clause will be protected for reasons unrelated to the scope of the agreement not to strike. In Mastro Plastics Corp. v. NLRB, ${ }^{150}$ for example, serious employer unfair labor practices were held, in effect, to justify nonperformance of the no-strike obligation. ${ }^{157}$ Another example is where picket line violence occurs, and individual employees attempting to cross become apprehensive about their personal safety. Although fear of a picket line may be deemed not to fall within the protection of section $7,{ }^{158}$ a no-strike clause otherwise governing the employees might be preempted by the mandate of section 502 of the LMRA, ${ }^{159}$ declaring refusals to work in the face of abnormally dangerous working conditions not to be a "strike." An invocation of section 502 must of course be supported by objective proof of abnormally dangerous working conditions in conformance with the guidelines established by Gateway Coal. ${ }^{160}$

iss But see General Am. Transp. Corp., 228 N.L.R.B. No. 102 (1977), and Roy Robinson, Inc., 228 N.L.R.B. No. 103 (1977), where a sharply divided Board restricted the scope of its Collyer doctrine by ruling that issues raised in $\S 8(\mathrm{a})(1), 8(\mathrm{a})(3), 8(\mathrm{~b})(1)(\mathrm{A})$ and $8(\mathrm{~b})(2)$ cases are not suitable for deferral to arbitration even though they arguably also involve contract violations.

1s6 350 U.S. 270 (1956); see Cox, The Legal Nature of Collective Bargaining Agreements, 57 MicH. L. REv. 1, 15.18 (1958).

${ }^{157}$ It should be noted, however, that serious employer unfair labor practices were not the cause of the refusal to work in any of the picket line respect cases in which Boys Markets injunctions were found to be appropriate prior to Buffalo Forge. For the Board's application of the Mastro Plastics doctrine in an unfair labor practice case involving picket line respect, see Pilot Freight Carriers, Inc., 224 N.L.R.B. No. 46 (1976).

158 NLRB v. Union Carbide Corp., 440 F.2d 54 (4th Cir.), cert. denied, 404 U.S. 826 (1971).

13s 29 U.S.C. § 143 (1970).

100 See Plain Dealer Publishing Co. v. Cleveland Typographical Union 53, 520 F.2d 1220 (6th Cir. 1975), cert. denied, 428 U.S. 909 (1976), where an alternative ground for denying injunctive relief was that the picket line and the threats of violence accompanying it created an abnormally dangerous working condition. The Board discussed the application of $\S 502$ to threats of violence in Redwing Carriers, 130 N.L.R.B. 1208 (1961), finding insufficient objective evidence of an abnormally dangerous working condition to warrant invoking the protec- 


\section{Sympathy Strikes, Respect for Picket Lines, and Union RESPONSIBILITY}

If a labor organization resisting Boys Markets relief cannot be held accountable for the actions of its members because they have acted contrary to its instructions, then a court's authority to enjoin the action of individual employees over whom it may not have personal jurisdiction is called into question. ${ }^{161}$ Typically, an injunction issued under the authority of Boys Markets will restrain not only the labor organization but also its "officers, agents, representatives, members and all persons acting in concert, aid or participation with them."162 However, the presumption that the labor organization and its members act in concert is frequently questioned in the context of sympathy strikes or refusals to cross another union's picket line. These forms of industrial action are often portrayed as consisting solely of individual decisions taken as a matter of conscience contrary to the union's instructions, or as based on the fear that crossing a picket line may lead to violence.

Of course, if only a few employees respect a picket line and production is not substantially affected, the employer's burden of showing irreparable harm if the injunction is denied would seem insurmountable. Injunctive relief could be denied for this reason alone, with the employer limited to the remedy of discipline or discharge of the employees involved. ${ }^{163}$ However, where employees engage in a sympathy strike or respect of another union's picket line in breach of a no-strike obligation, and irreparable harm to the employer can be demonstrated, an injunction, if otherwise appropri-

tions of $\S 502$. Of course, where the "abnormally dangerous working condition" created by the picket line is due to picket line violence or threats of violence, state court injunctions against those engaging in violent picketing are not preempted, see San Diego Bldg. Trades Council v. Garmon, 359 US. 236 (1959), and the anti-injunction provisions of the NorrisLaGuardia Act do not deprive the federal courts of jurisdiction to issue injunctions. 29 U.S.C. $\S 104(\mathrm{e})(1970)$.

${ }^{181}$ A court has jurisdiction over an individual in a $\S 301$ suit if the individual is a party. See Smith v. Evening News Ass'n, 371 U.S. 195 (1962). But it is impractical, if not impossible, to join all the individual workers participating in a breach of contract strike as parties. Consequently, an injunction order may not bind individuals not joined as parties unless they are "officers, agents, servants, employees, [or] attorneys" of parties or are acting "in active concert or participation" with parties and have actual notice of the suit. FED R. CIV. P. 65(d).

102 Boy's Markets, Inc. v. Retail Clerks, 70 L.R.R.M. 3071, 3076 (C.D. Cal. 1969) (injunction decree).

103 Whether individual employees who participate in an unauthorized strike are liable to employers for damages was left unanswered in Atkinson v. Sinclair Ref. Co., 370 U.S. 238, 249 n.7 (1962), and was resolved in favor of nonliability in Sinclair Oil Corp. v. Oil Workers, 452 F.2d 49 (7th Cir. 1971), noted in 86 HaRv. L. REv. 447 (1972); 18 WAYNE L. REv. 1657 (1972). 
ate, should issue against the union and its individual members, despite any claims of union nonresponsibility. ${ }^{184}$

Outside the context of respect for picket lines, the issue of union responsibility for unauthorized strikes by a substantial minority, or even a majority, of its membership is not settled. ${ }^{165}$ One body of authority argues that absent a specific contractual provision imposing union responsibility for unauthorized strikes, liability for "wildcat" walkouts should not be imposed because awarding damages would deplete the union treasury and the burden of liability would destroy the union as an institution. ${ }^{186}$ Opposed is a line of authority drawing on common law agency doctrines and contending that not to hold unions responsible for mass unauthorized actions of their membership would destroy unionism by fostering anarchy. ${ }^{167}$

16 On remedies for wildcat strikes, see Spelfogel, Wildcat Strikes and Minority Concerted Activity-Discipline, Damage Suits and Injunctions, 24 LAB. L.J. 592, 611-15 (1973). The Constitution does not confer an absolute right to strike or to engage in concerted refusals to work. Assuming that irreparable harm to the employer by the refusal of a few individuals to work could be shown, injunctive relief solely against the individuals who refuse to cross picket lines but who do not sever their employment relationship would not seem to contravene notions of due process or the thirteenth amendment's prohibition against involuntary servitude, particularly when express or implied no-strike obligations govern. See Dorchy v. Kansas, 272 U.S. 306, 311 (1926). See also Eazor Express, Inc. v. International Bhd. of Teamsters, 520 F.2d 951 (3d Cir. 1975).

tos See generally Fishman \& Brown, Union Responsibility for Wildcat Strikes, 21 WaynE L. REv. 1017 (1975); Gould, The Status of Unauthorized and "Wildcat" Strikes Under the National Labor Relations Act, 52 Cornell L. Rev. 672 (1967); Whitman, Wildcat Strikes: The Unions' Narrowing Path to Rectitude? 50 IND. L.J. 472 (1975). The standard for assessing union responsibility in $\S 301$ actions is set forth in $\S \S 301$ (b) \& (e)-incorporating ordinary doctrines of agency - rather than $\S 6$ of the Norris-LaGuardia Act, which requires clear proof of actual authorization or ratification after actual knowledge. See UMW v. Gibbs, 383 U.S. 715,736 (1966); Lewis v. Benedict Coal Corp., 259 F.2d 346 (6th Cir. 1958), aff'd by an equally divided court on this issue, 361 U.S. 459 (1960); Central Appalachian Coal Co. v. UMW, 376 F. Supp. 914, 922-24 (S.D.W. Va. 1974); but see United States Steel Corp. v. UMW, 519 F.2d 1249 (5th Cir. 1975) (suggesting that the company's burden of proof on the issue of union responsibility should be greater in the absence of an express no-strike obligation and that a series of past wildcat strikes might make it more difficult for a union to exculpate itself from liability).

it See, e.g., North Am. Coal Corp. v. Local 2262, UMW, 497 F.2d 459 (6th Cir. 1974); Penn Packing Co. v. Meatcutters Local 195, 497 F.2d 888 (3d Cir. 1974); Harnischfeger Corp. v. Sheet Metal Workers, 436 F.2d 351 (6th Cir. 1970); United Constr. Workers v. Haislip Baking Co., 223 F.2d 872 (4th Cir.), cert. denied, 350 U.S. 847 (1955).

${ }^{167}$ See, e.g., United States v. Brotherhood of R.R. Trainmen, 96 F. Supp. 428 (N.D. Ill. 1951); United States v. International Union, UMW, 77 F. Supp. 563, 566 (D.D.C. 1948), aff'd, 177 F.2d 29 (D.C. Cir.), cert. denied, 338 U.S. 871 (1949). In Eazor Express, Inc. v. International Bhd. of Teamsters, 520 F.2d 951 (3d Cir. 1975), a $\$ 301$ damage action, the contractual no-strike obligation was held to impose on the union by implication an affirmative obligation to use "every reasonable means" to end unauthorized strikes. The decision has been criticized. Whitman, supra note 165; 89 HARv. L. Rev. 601 (1976). But see Fishman \& Brown, supra note 165. In United States Steel Corp. v. UMW, 548 F.2d 67, (3d Cir. 1976), the court extended the Eazor analysis to an injunction action and held that an affirmative obligation 
Both of these extremes seem far-fetched. Putting aside speculation about impending industrial anarchy and the ultimate destruction of unions as institutions, it seems clear that the bargaining agreement and the institution of collective bargaining would be impaired by allowing the union to claim nonresponsibility. The institution of bargaining and the bargaining agreement have provided unions with the means of resisting arbitrary and irrational employer action. Permitting unions to plead nonresponsibility for the claimed arbitrary and irrational mass actions of their members may in turn encourage employers to react irresponsibly, frustrating and impeding the bargaining process. Moreover, in the context of a sympathy strike or picket line respect by a substantial complement of the bargaining unit, a claim of union nonresponsibility is not entirely consistent with reality. As Justice Stevens noted in Buffalo Forge, such activity may be adverse to the economic interests of the individuals engaging in it. In fact, sympathy strikes and picket line respect by employees have been minimal, if not nonexistent, when their labor organization declares that the line need not be respected or is unworthy of respect. ${ }^{168}$

\section{Conclusion}

The Supreme Court majority in Buffalo Forge failed to recognize that when the parties' agreement contains an unqualified nostrike clause, important goals of labor policy are served by enjoining sympathy work stoppages pending expedited arbitration of the scope of the no-strike obligation. Injunctive relief pending the arbitrator's decision would strengthen the bargaining agreement, encourage collective bargaining as an institution, and foster utilization of the parties' dispute adjustment procedures. The remedy could be tailored to avoid the pitfall of determining the merits of the controversy in an injunction proceeding in a manner that would render the parties' own dispute procedures superfluous. An order preserving the status quo pending an arbitral determination of an intertwined unfair labor practice and contractual issue concerning the right to engage in a sympathy strike or picket line respect would discourage judicial intervention into the thicket of Board law. It would also be consistent with the policies favoring labor arbitration developed in section 301 cases.

to end an unauthorized strike was appropriate even though the no-strike obligation itself was implied from grievance-arbitration provisions.

${ }^{16 s}$ See Raskin, supra note 125, at 15. 
By declaring that the sympathy strike issue was arbitrable at the employer's request when employer breach-of-contract claims were excluded from the contractual grievance procedures preceding arbitration, Buffalo Forge may also have the effect of foreclosing judicial intervention into breach-of-contract strikes in section 301 damage actions. Such a result would be unfortunate from a policy and a practical standpoint not only because the issue was not argued in Buffalo Forge, but also because Atkinson v. Sinclair Refining Co. ${ }^{169}$ represents sound contractual analysis which has not been seriously questioned. The relationship between a breach-ofcontract injunction remedy and access to arbitration should mirror the relationship between an employer's section 301 damage remedy and arbitration under Atkinson v. Sinclair. When the arbitral forum has been made available to both parties, the merits of their controversy should be determined by an arbitrator, with the court intervening only to restore the status quo by specifically enforcing a nostrike obligation pending the arbitrator's award on the merits. In contrast, when the employer's breach-of-contract claim has been excluded from arbitration, the employer should be limited to the damage remedy.

When equitable intervention is restricted in this manner, the Norris-LaGuardia Act retains its vitality, depriving courts of authority to enforce no-strike obligations when the parties have not provided for arbitral resolution of disputes over the application of the no-strike clause. Confining the injunction remedy to disputes subject to arbitration also commits to the bargaining process the decision to make injunctive relief available. The parties, in determining which controversies between them are subject to arbitration, will also determine the circumstances in which a remedy restraining a strike in breach of contract pending arbitration is appropriate.

16 370 U.S. 238 (1962); see text at notes 54 \& 118 supra. 